\title{
Influence of the Main Design Factors on the Optimal Fuel Cell-Based Powertrain Sizing
}

\author{
Carmen Raga, Andres Barrado*(D), Antonio Lazaro, Alberto Martin-Lozano, Isabel Quesada \\ and Pablo Zumel
}

Power Electronics Systems Group, Universidad Carlos III de Madrid, 28911 Leganes, Spain; carmen.raga@gmail.com (C.R.); alazaro@ing.uc3m.es (A.L.); albermar@ing.uc3m.es (A.M.-L.); isabel.quesada@gmail.com (I.Q.); pzumel@ing.uc3m.es (P.Z.)

* Correspondence: barrado@ing.uc3m.es; Tel.: +34-91-624-9188

Received: 4 October 2018; Accepted: 31 October 2018; Published: 7 November 2018

check for updates

\begin{abstract}
The design of the optimal power distribution system (PDS or powertrain) for fuel cell-based vehicles is a complex task due to PDS comprising one or more power converters, several types of secondary energy sources, a fuel cell, several control loops, and protections, among others. The optimized powertrain design tries to minimize the mass, volume, and cost, and also to improve system efficiency, fuel economy (both hydrogen and electricity), and vehicle autonomy. This paper analyzes the influence of four different factors that deeply affect the optimal powertrain design, in particular: the minimum power delivered by the fuel cell, the storage of the recovered energy from the regenerative braking periods, the battery technology, and the maximum battery state-of-charge variation. The analysis of these factors is carried out over a set of 9 different fuel cell-based architectures applied to a light vehicle, and a 10th architecture corresponding to a pure electric vehicle. This analysis provides the knowledge of how these design factors affect the mass, volume, and cost of the optimal power distribution architectures, and how they can be considered in the design.
\end{abstract}

Keywords: sizing; battery and supercapacitor; fuel cell; powertrain; power distribution system; vehicles

\section{Introduction}

Fuel cell (FC)-based vehicles present growing reliability and autonomy [1-3], which is the reason they are beginning to be considered a strong alternative to internal combustion engine vehicles. One of the challenges of fuel cell-based vehicles is the design of the power distribution system (PDS or powertrain). The powertrain must be able to overcome the major drawbacks of the fuel cell: load-dependent output voltage, unidirectional power flow, slow dynamic response, and other operating characteristics, such as high-temperature startup, very long startup times, and overshoot or overdamped transient responses [4-6].

Fuel cell-based vehicles are strategically focused on improving the maximum speed, acceleration, autonomy, and cost [7]. Therefore, minimizing the mass and cost of the powertrain is of great importance to the maximization of autonomy and fuel saving, and the achievement of a competitive price. The elements that comprise the propulsion system are the fuel cell system, the DC-DC power converters, and the energy storage devices (batteries and supercapacitors).

The selection of the most suitable fuel cell-based power distribution system is a complex task that has a significant influence on the vehicle mass, volume, cost, autonomy, efficiency, etc. In fact, there is an extensive range of possibilities in the design of a fuel cell-based power distribution system. These possibilities depend on the number, location, and kind of energy storage devices and power 
converters, as well as on the control strategy and the storage of energy from the regenerative braking periods [8-12].

Some papers in the literature analyze and compare different PDSs based on fuel cells and batteries [7,8,11,13], based on fuel cells and supercapacitors [9,14-17], and, finally, based on fuel cells, batteries, and supercapacitors [10,18-22]. In [23], a complete analysis and comparison of 10 different power distribution systems are presented, considering all the possibilities in powertrain implementation (fuel cell and batteries, fuel cell and batteries and supercapacitors, fuel cell and supercapacitors). Also provided in [23] is an optimal sizing procedure for fuel cell-based architectures, in which the minimum cost and mass are calculated as a function of the maximum power delivered by the fuel cell. All the analyses are carried out for a light vehicle of $800 \mathrm{~kg}$, operating during a working day of $8 \mathrm{~h}$ with the European urban driving cycle ECE-15. The subsystems considered in the PDS are the fuel cell stack, the fuel cell hydrogen tank, the battery, the supercapacitors, and the DC-DC power converters [24-27].

Considering, as a starting point, the optimal sizing procedure presented in [23], this paper analyzes the influence of four different design factors on the mass and cost of the PDS, continuing with the work presented in [28], in which the influence of the driving profile is analyzed. These factors are the minimum power delivered by the fuel cell, the energy storage from the regenerative braking periods, the battery technology, and, finally, the maximum battery state-of-charge variation. These design factors can vary significantly not only in the mass, volume, and cost of the complete PDS but also the selection of the optimal power distribution architectures.

This paper organizes as follows. Section 2 describes the power distribution architectures that constitute the power distribution systems, as well as the main vehicle characteristics. Section 3 reviews the influence of applying the different driving profiles described in [28]. The influence of the minimum power delivered by the fuel cell is analyzed in Section 4 . Section 5 describes the effect of considering the storage of the energy recovered from the regenerative braking periods when it is bigger than the energy delivered by the secondary energy sources. Section 6 describes the influence of using different battery technologies, and, finally, Section 7 analyzes the effect of imposing a different state-of-charge variation to the secondary energy sources. Section 8 summarizes the conclusions collected throughout this research paper.

\section{Power Distribution Systems and Vehicle Characteristics}

Different power distribution systems (PDSs) can be implemented depending on the number and location of the elements that comprise each architecture, particularly a fuel cell, a battery, one or more DC-DC power converters, and the supercapacitors [23] (see Figure 1). Of all of these elements, the fuel cell is the primary energy source. Additionally, for the sake of comparison, a 10th architecture is considered, which corresponds to a pure electric vehicle (OB). This architecture has been included in the analysis to highlight and compare the advantages and drawbacks between a pure electric car and a fuel cell-based vehicle, regarding mass and cost.

Applying the optimal sizing procedure described in [23], the minimum sum of battery mass and supercapacitor mass can be calculated depending on the maximum power delivered by the fuel cell. These results determine the most suitable range of the maximum fuel cell power for each architecture. Also, this procedure has allowed the grouping of architectures depending on the nature of the secondary energy sources: those that use only batteries, a combination of batteries and supercapacitors, or only supercapacitors, as shown in Figure 1.

All the analyses are developed for a light vehicle of $800 \mathrm{~kg}$. The considered electrical efficiency from the wheels to the motor drive is 0.75 , the unidirectional DC-DC power converter efficiency is 0.95 , the bidirectional DC-DC power converter efficiency is 0.9 , and the considered fuel cell system efficiency is 0.6 . The battery and supercapacitor efficiencies are 0.95 . For the case where a three-port converter is used, two equivalent two-port converters can be obtained with a mass, volume, and cost that are proportional to the power delivery by each port. Finally, the cost of every PDS is obtained 
considering the production of 500,000 units. All these data and the further interesting information discussed below has been obtained from [23].

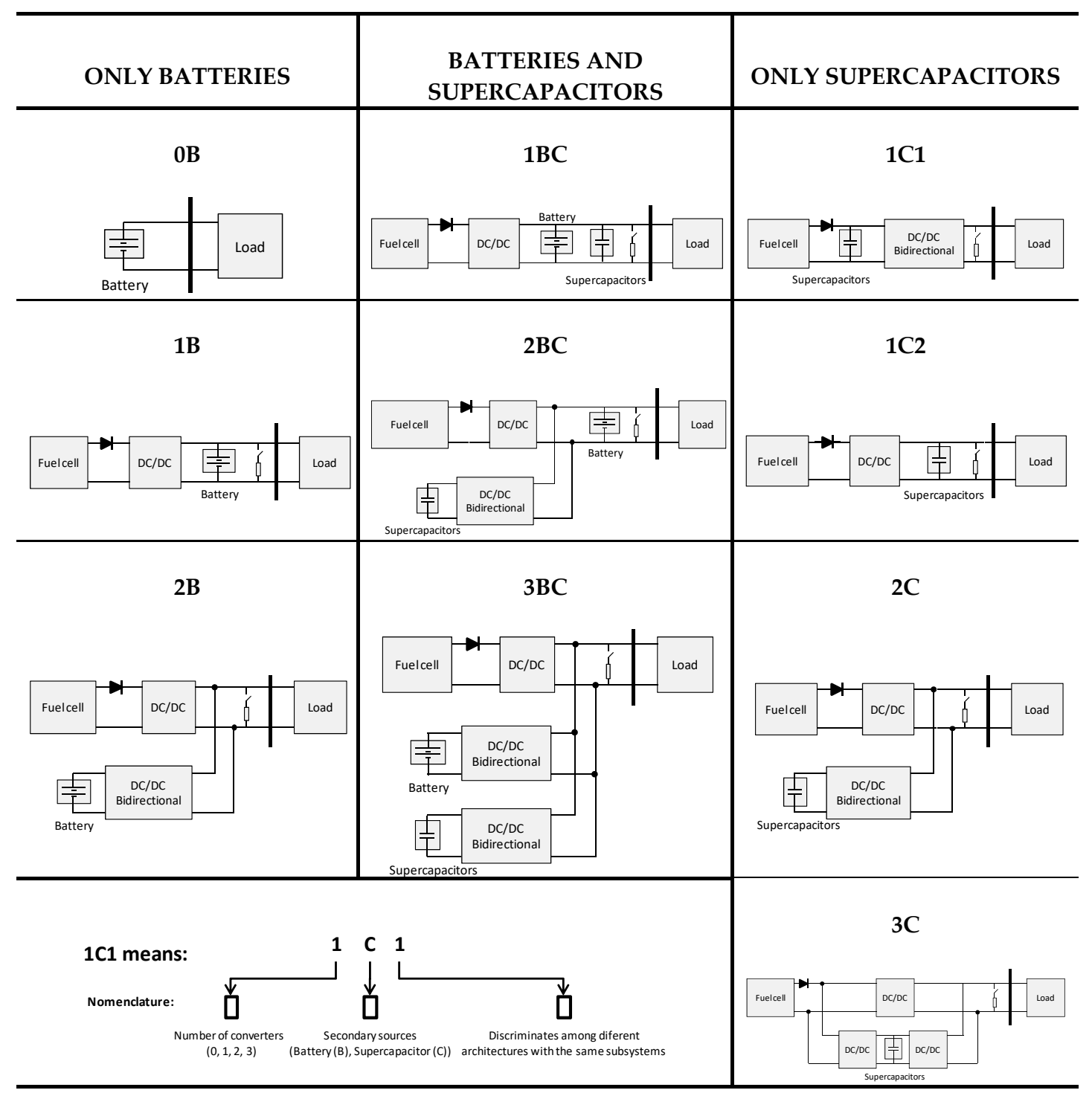

Figure 1. Power distribution architectures based on the fuel cell, supercapacitors, and battery [23].

\section{Driving Profile Influence}

The influence of the driving profile was already analyzed in [28]. In this paper, this influence is reviewed for a better understanding of the rest of the paper.

Three different European driving profiles, listed in Table 1, are used to evaluate the internal combustion engines (ICE) regarding pollutant emissions and fuel economy [29]; these profiles are considered here to analyze the influence of the driving profile on the size, volume, and cost of the power distribution systems. Each driving profile implies a different power profile, as shown in Figure 2 [28].

Table 1. European driving profiles.

\begin{tabular}{ccc}
\hline Driving Profile & Maximum Speed & Total Time \\
\hline Urban Driving Cycle for light vehicles, ECE-15 or UDC & $50 \mathrm{~km} / \mathrm{h}$ & $195 \mathrm{~s}$ \\
Extra Urban Driving Cycle for Low power vehicles, EUDCL & $90 \mathrm{~km} / \mathrm{h}$ & $400 \mathrm{~s}$ \\
Extra Urban Driving Cycle, EUDC & $120 \mathrm{~km} / \mathrm{h}$ & $400 \mathrm{~s}$ \\
\hline
\end{tabular}




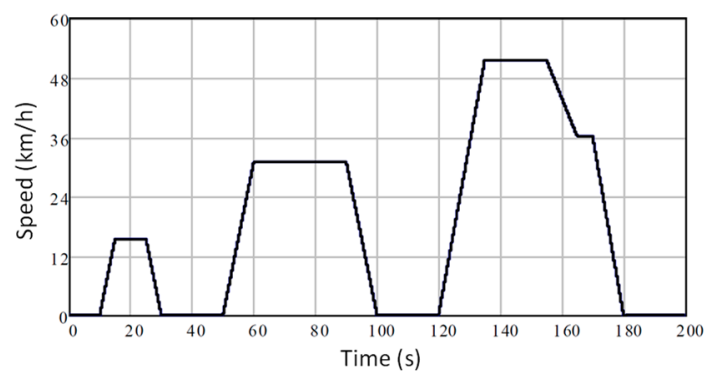

(a)

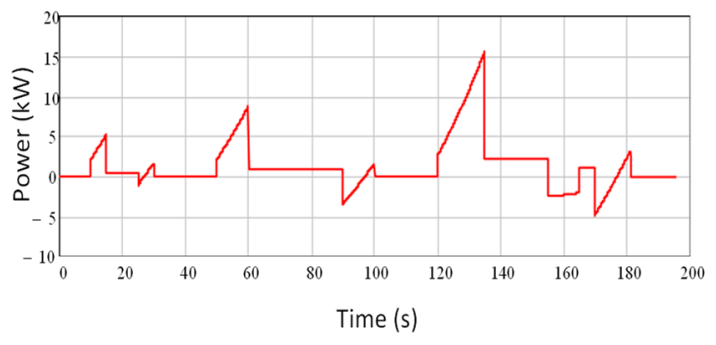

(b)

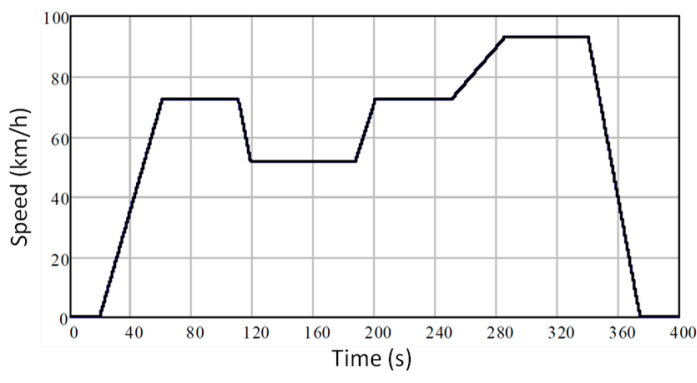

(c)

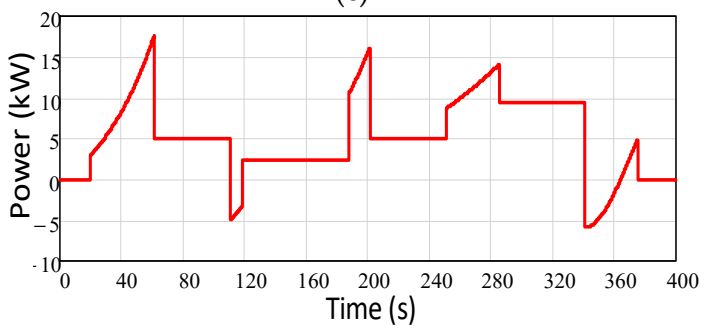

(d)

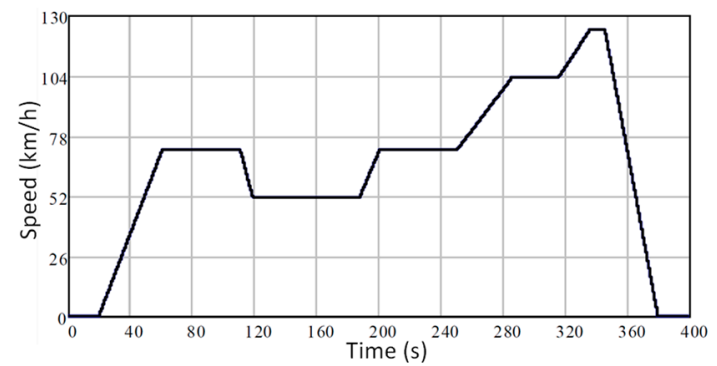

(e)

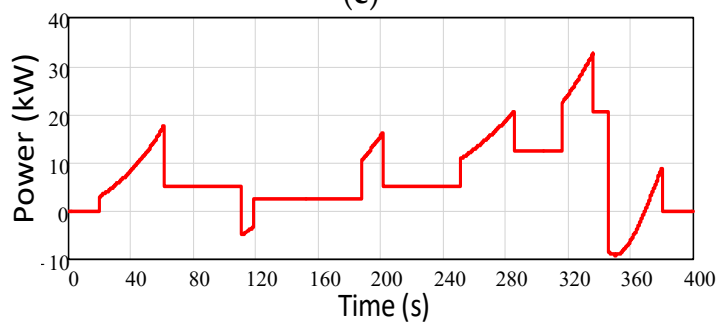

(f)

Figure 2. (a) ECE-15 driving profile. (b) Power demand under ECE-15 driving profile. (c) EUDCL driving profile. (d) Power demand under EUDCL driving profile. (e) EUDC driving profile. (f) Power demand under EUDC profile. Power demands have been obtained for a light vehicle [28].

Figure 3 shows the normalized battery and supercapacitor mass evolution depending on the maximum fuel cell power, obtained by the procedure described in [23]. The influence of the driving profile can be noticed in the power level that limits each region, as shown in Table 2.

As can be noticed, for the lower fuel cell maximum power, only batteries achieve the PDS minimum mass. At the highest fuel cell maximum power range, the PDS minimum mass is achieved by only supercapacitors, although this power region is very narrow. Finally, in the intermediate range of fuel cell maximum power, the PDS minimum mass is achieved using both batteries and supercapacitors. 


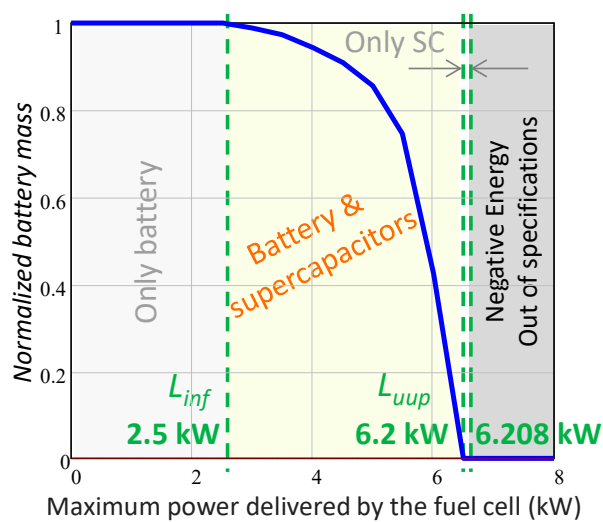

(a)

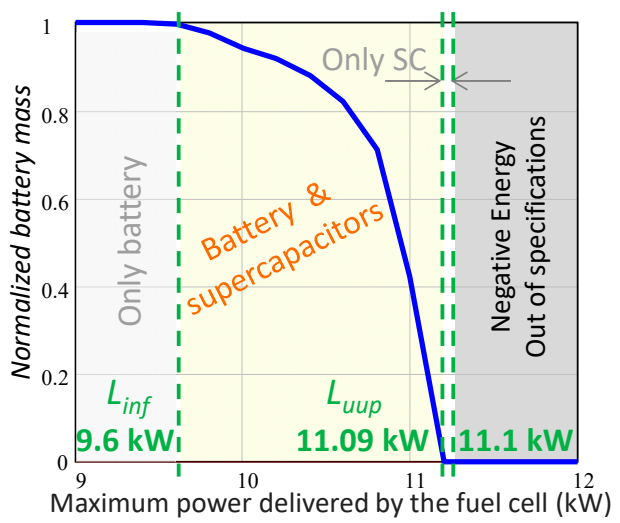

(b)

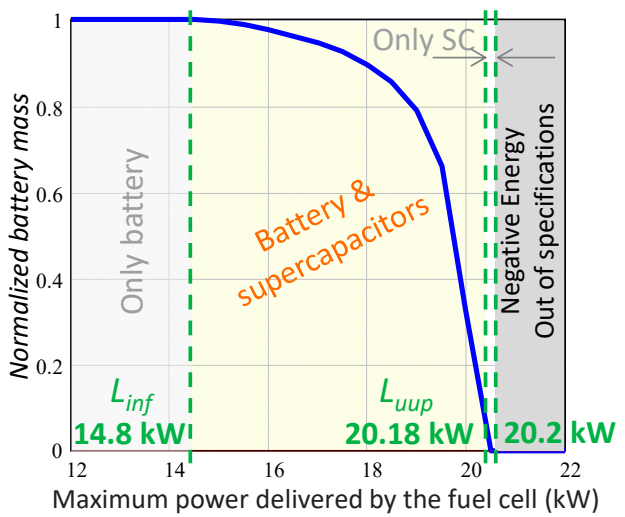

(c)

Figure 3. Normalized battery mass evolution depending on the maximum power delivered by the fuel cell for architecture 1B: (a) ECE-15 cycle. (b) EUDCL cycle. (c) EUDC cycle [28].

Table 2. Power range limits for the analyzed European driving profiles.

\begin{tabular}{cccc}
\hline & \multicolumn{2}{c}{ European Driving Profiles } & EUDC \\
\hline Power Ranges & ECE-15 & EUDCL & 0 kW to $L_{\text {inf }}=14.8 \mathrm{~kW}$ \\
Only batteries & $0 \mathrm{~kW}$ to $L_{\text {inf }}=2.5 \mathrm{~kW}$ & $0 \mathrm{~kW}$ to $L_{\text {inf }}=9.6 \mathrm{~kW}$ & $0 \mathrm{kp}$ \\
Batteries and supercapacitors & $L_{\text {inf }}=2.5 \mathrm{~kW}$ to $L_{\text {upp }}=6.2 \mathrm{~kW}$ & $L_{\text {inf }}=9.6 \mathrm{~kW}$ to $L_{\text {upp }}=11.09 \mathrm{~kW}$ & $L_{\text {inf }}=14.8 \mathrm{~kW}$ to $L_{\text {upp }}=20.18 \mathrm{~kW}$ \\
Only supercapacitors & $L_{\text {upp }}=6.2 \mathrm{~kW}$ to $6.208 \mathrm{~kW}$ & $L_{\text {upp }}=11.09 \mathrm{~kW}$ to $11.1 \mathrm{~kW}$ & $L_{\text {upp }}=20.18 \mathrm{~kW}$ to $20.2 \mathrm{~kW}$ \\
\hline
\end{tabular}

Applying this analysis to every PDS shown in Figure 1, it is apparent that the optimal power distribution architectures are the same, independent of the applied driving profile. This optimal PDSs are $1 \mathrm{~B}, 1 \mathrm{BC}$, and $1 \mathrm{C} 2$. Also, in the case where energy and power delivery by the battery and the supercapacitors in the $1 \mathrm{BC}$ architecture cannot be controlled independently, the $1 \mathrm{BC}$ architecture can be replaced by the $2 \mathrm{BC}$ architecture. A more detailed explanation can be found in [28].

\section{Influence of the Minimum Power Delivered by the Fuel Cell}

Due to their performances, fuel cells are growing as an alternative for use in hybrid vehicles. However, their operating characteristics make it mandatory to design the PDS, control loops, and energy management strategies to mitigate their slow dynamic response, load-dependent output voltage, unidirectional operation, long startup times, low-temperature startup, and overshoot and overdamped transient responses $[4,6,30,31]$. Indeed, since the startup time can last for tens of seconds, the minimum fuel cell-delivered power must be considered for avoiding unexpected fuel cell shutdowns, as Figure 4 depicts. 


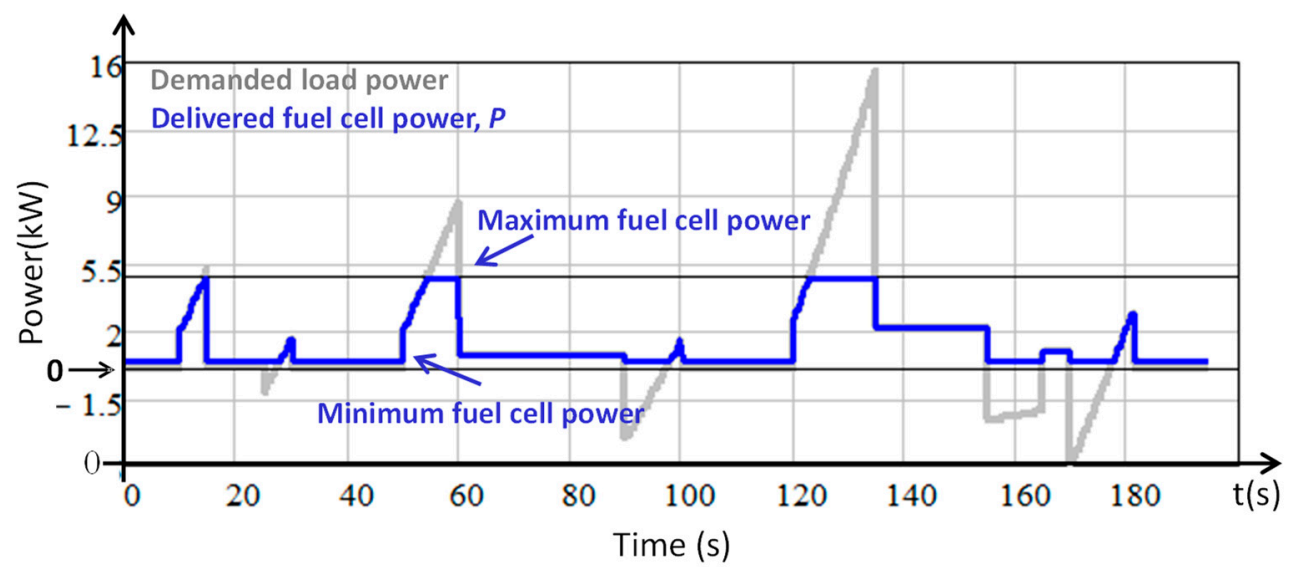

Figure 4. Fuel cell-delivered power: a minimum value of $400 \mathrm{~W}$ and maximum value of $4.7 \mathrm{~kW}$ for the ECE-15 profile applied to a light vehicle.

The gray line represents the power demanded by the load, and the blue line represents the power delivered by the fuel cell.

Because the tendencies are the same for the three analyzed profiles, in this section, three different minimum power values are applied-0 W, $200 \mathrm{~W}$, and $400 \mathrm{~W}$, considering the same ECE-15 driving cycle only - to evaluate the influence of the fuel cell minimum power.

Figure 5 shows the new optimal power ranges for each group of architecture as a function of the fuel cell minimum power. It can be seen that both power limits ( $L_{\text {inf }}$ and $L_{u p p}$ ) are shifted toward lower fuel cell maximum power values when the minimum power increases. This effect is because a higher fuel cell minimum power implies a larger amount of energy delivered by the fuel cell. As a consequence, the power range with only batteries is reduced as the minimum fuel cell power increases, since the equivalent energy and power load requirements are lower.

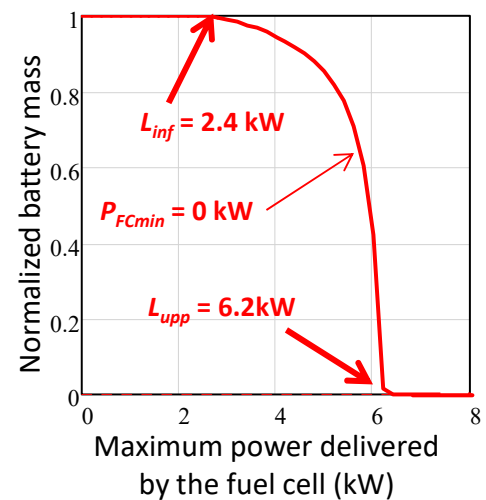

(a)

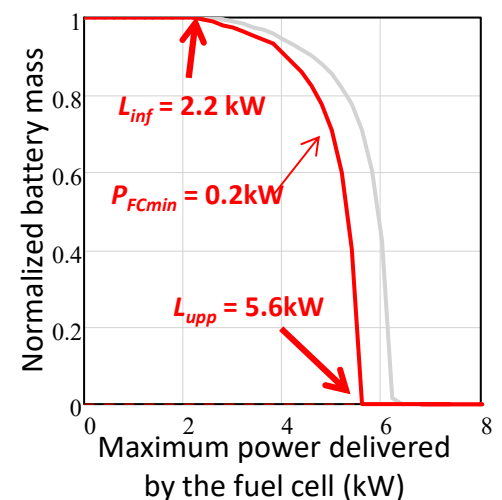

(b)

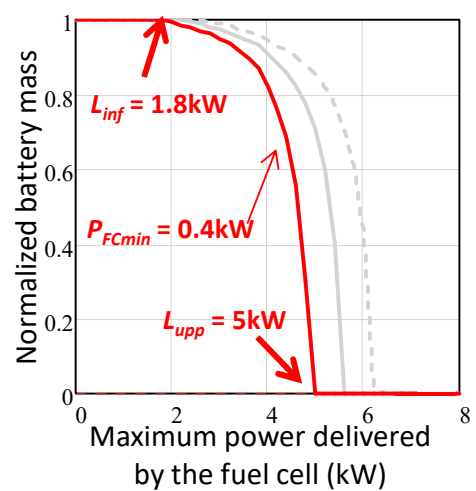

(c)

Figure 5. Influence of the fuel cell (FC) minimum power on the normalized battery mass: (a) FC minimum power of $0 \mathrm{~W}$. (b) FC minimum power of $200 \mathrm{~W}$. (c) FC minimum power of $400 \mathrm{~W}$.

Figure 6 shows the optimal mass, volume, and cost of each architecture evaluated in their optimal power range with the three different minimum power values [23]. 


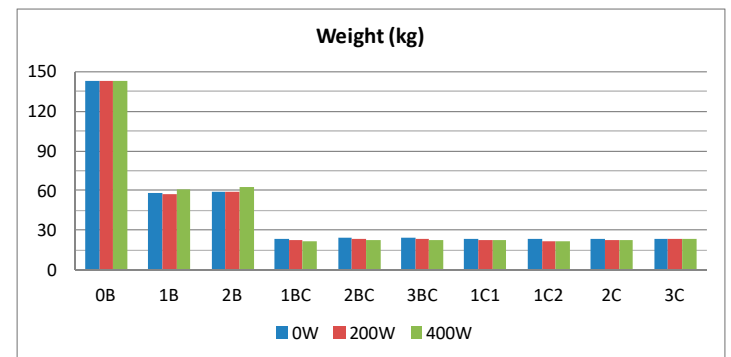

(a)

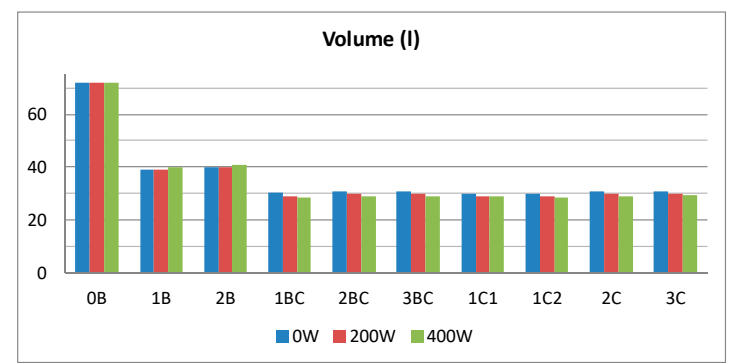

(b)

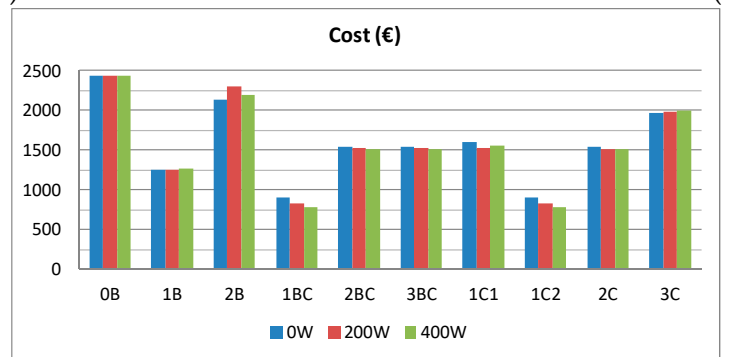

(c)

Figure 6. Influence of the fuel cell minimum power the power distribution system (PDS): (a) Mass, (b) Volume. (c) Cost.

Figure 6 shows, for each architecture group, the PDSs that present optimal mass, volume, and cost, depending on the fuel cell minimum power. Among them, the best performances are again achieved with the architectures $1 B, 1 B C$, and $1 C 2$, like in the previous section. Additionally, as the delivered minimum power by the fuel cell increases, the architectures based only on supercapacitors and those based on batteries together with supercapacitors, 1BC and 1C2, experience a decrease in their overall mass and volume. However, architecture 1B presents different behavior concerning architectures 1BC and $1 \mathrm{C} 2$.

Architecture 1B presents a mass, volume, and cost increase as the fuel cell minimum power increases, whereas architectures $1 B C$ and 1C2 suffer a mass, volume, and cost reduction. It is because if the fuel cell minimum power increases, $P_{F C m i n}$, the design power limit for the PDS with only batteries, $L_{\text {inf }}$, decreases. The higher the fuel cell minimum power, $P_{F C m i n}$, the higher the battery total mass needed to satisfy the load requirements. In other words, increasing the fuel cell minimum power, $P_{\text {FCmin }}$, implies a smaller design power limit $L_{\text {inf }}$, which means a lower fuel cell maximum power, and, therefore, the minimum battery mass must be higher, as Figure 7 depicts.

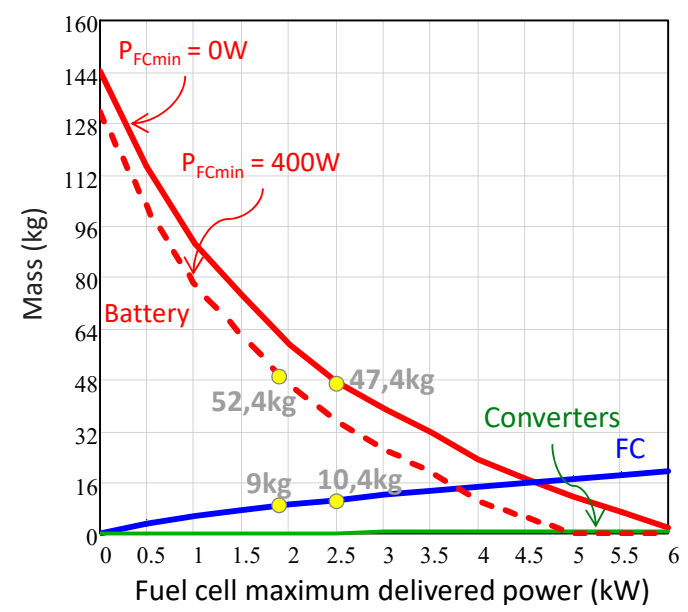

Figure 7. Battery, fuel cell system, and DC-DC converter mass evolution depending on the maximum power delivered by the fuel cell in architecture 1B. 
Figure 7 shows the fuel cell system, battery, and DC-DC converter mass evolution for architecture $1 \mathrm{~B}$, depending on the fuel cell maximum power delivered, when two different values of the fuel cell minimum power are used, $0 \mathrm{~W}$ and $400 \mathrm{~W}$. For a fuel cell minimum power value of $0 \mathrm{~W}$, the power design limit for a battery-based PDS is $L_{\text {inf }}=2.5 \mathrm{~kW}$, as shown in Figure $5 \mathrm{a}$. On the other hand, for a fuel cell minimum power of $400 \mathrm{~W}$, the design power limit for a battery-based PDS is $L_{\text {inf }}=1.8 \mathrm{~kW}$, as in Figure 5c. The battery masses for these two limits are $47.4 \mathrm{~kg}$ (for $L_{\text {inf }}=2.5 \mathrm{~W}$ ) and $52.4 \mathrm{~kg}$ (for $L_{\text {inf }}=1.8 \mathrm{~kW}$ ), respectively (Figure 7). This means that the battery mass related to the lower design power limit, $L_{\text {inf }}=1.8 \mathrm{~kW}$, is larger than the battery mass related to the higher design power limit, $L_{\text {inf }}=2.5 \mathrm{~kW}$.

With the new lower power limit in the region of architecture 1B, the fuel cell and power converter mass, volume, and cost reduction are smaller than the battery mass, volume, and cost increment, as shown in Figure 7. Therefore, for those architectures that use only batteries as secondary energy sources, the overall mass, volume, and cost increase with the fuel cell minimum power $P_{F C m i n}$.

On the contrary, in architectures $1 \mathrm{BC}$ and $1 \mathrm{C} 2$, the fuel cell and power converter mass, volume, and cost reduction are more significant than the energy storage devices mass, volume, and cost increment.

Tables 3-5 show the optimal mass, volume, and cost for each architecture, evaluated in their optimal design power range, under the three considered FC minimum power values. Additionally, each table includes two columns, in which the mass, volume, and cost reduction are shown, in percentage. By considering $0 \mathrm{~W}$ as a reference, one column shows the percentage variations obtained when the minimum power is established as $200 \mathrm{~W}$, and the other shows the percentage variations obtained when the minimum power is $400 \mathrm{~W}$. The colors toward green and the upwards pointing arrows indicate an improvement in mass, volume or cost and, the colors toward red and the downward pointing arrows indicate a worsening in mass, volume or cost.

Table 3. Influence of the fuel cell minimum power on PDS mass for the ECE-15 profile.

\begin{tabular}{|c|c|c|c|c|c|c|}
\hline$P_{f c m i n}$ & $0 \mathrm{~W}$ & $200 \mathrm{~W}$ & $400 \mathrm{~W}$ & \multicolumn{3}{|c|}{ Mass reduction $(\%)$} \\
\hline Weight (kg) & ECE-15 & ECE-15 & ECE-15 & $0 W-200 W$ & $0 W-4$ & $100 \mathrm{~W}$ \\
\hline $\mathrm{OB}$ & 144.3 & 144.3 & 144.3 & $\Rightarrow \quad 0.0$ & $\Rightarrow$ & 0.0 \\
\hline $1 \mathrm{~B}$ & 58.2 & 57.5 & 61.7 & $\Rightarrow \quad 1.2$ & $\sqrt{3}$ & -6.0 \\
\hline $2 \mathrm{~B}$ & 59.8 & 59.2 & 63.4 & $\Rightarrow \quad 1.0$ & ת & -6.0 \\
\hline $1 B C$ & 23.2 & 22.2 & 21.3 & \ 4.7 & 仓े & 8.2 \\
\hline $2 \mathrm{BC}$ & 24.4 & 23.4 & 22.6 & ¿ 4.1 & 仓 & 7.4 \\
\hline $3 B C$ & 24.4 & 23.4 & 22.6 & 4.1 & ૫ & 7.4 \\
\hline $1 \mathrm{C} 1$ & 24.7 & 23.7 & 22.9 & 4.0 & 仓े & 7.3 \\
\hline $1 \mathrm{C} 2$ & 23.5 & 22.4 & 21.5 & $\gtrsim \quad 4.7$ & 仓े & 8.5 \\
\hline $2 \mathrm{C}$ & 24.6 & 23.6 & 22.8 & 4.1 & 仓े & 7.3 \\
\hline $3 C$ & 27.1 & 26.1 & 25.4 & 3.7 & نे & 6.3 \\
\hline
\end{tabular}


Table 4. Influence of the fuel cell minimum power on PDS volume for the ECE-15 profile.

\begin{tabular}{|c|c|c|c|c|c|}
\hline $\boldsymbol{P}_{\text {fcmin }}$ & $0 \mathrm{~W}$ & $200 \mathrm{~W}$ & $400 \mathrm{~W}$ & \multicolumn{2}{|c|}{ Volume reduction $(\%)$} \\
\hline Volume (1) & ECE-15 & ECE-15 & ECE-15 & $0 W-200 W$ & $0 W-400 W$ \\
\hline OB & 72.2 & 72.2 & 72.2 & 0.0 & У $\quad 0.0$ \\
\hline 1B & 39.1 & 38.6 & 40.3 & $\Rightarrow \quad 1.3$ & 万 -3.1 \\
\hline $2 \mathrm{~B}$ & 39.9 & 39.4 & 41.1 & 1.3 & -3.0 \\
\hline $1 B C$ & 29.9 & 29.1 & 28.5 & 2.7 & 4.7 \\
\hline $2 B C$ & 30.6 & 29.8 & 29.2 & 2.6 & 仓 4.6 \\
\hline $3 B C$ & 30.6 & 29.8 & 29.2 & 2.6 & 4.6 \\
\hline $1 \mathrm{C} 1$ & 30.8 & 30 & 29.4 & 2.6 & 4.5 \\
\hline $1 \mathrm{C} 2$ & 30.2 & 29.4 & 28.8 & 2.6 & 4.6 \\
\hline $2 \mathrm{C}$ & 30.7 & 30 & 29.4 & 2.3 & 4.2 \\
\hline $3 C$ & 32.0 & 31.3 & 30.7 & 2.2 & 4.1 \\
\hline
\end{tabular}

Table 5. Influence of the fuel cell minimum power on PDS cost for the ECE-15 profile.

\begin{tabular}{|c|c|c|c|c|c|}
\hline $\boldsymbol{P}_{f c m i n}$ & $0 \mathrm{~W}$ & $200 \mathrm{~W}$ & $400 \mathrm{~W}$ & \multicolumn{2}{|c|}{ Cost reduction $(\%)$} \\
\hline Cost $(€)$ & ECE-15 & ECE-15 & ECE-15 & $0 W-200 W$ & $0 W-400 W$ \\
\hline OB & 2454 & 2454 & 2454 & 万 0.0 & 马 0.0 \\
\hline $1 \mathrm{~B}$ & 1256 & 1230 & 1276 & $\unlhd \quad 2.1$ & 万 -1.6 \\
\hline $2 \mathrm{~B}$ & 2145 & 2138 & 2209 & 0.3 & 5 -3.0 \\
\hline $1 B C$ & 892 & 833.8 & 784.9 & 6.5 & 12.0 \\
\hline $2 \mathrm{BC}$ & 1538 & 1525 & 1514 & $\sqrt{7} \quad 0.8$ & $\unlhd \quad 1.6$ \\
\hline $3 B C$ & 1538 & 1525 & 1514 & 0.8 & 1.6 \\
\hline $1 \mathrm{C} 1$ & 1593 & 1574 & 1559 & 1.2 & 2.1 \\
\hline $1 \mathrm{C} 2$ & 903 & 844.6 & 796 & 6.5 & 11.8 \\
\hline $2 \mathrm{C}$ & 1543 & 1529 & 1519 & 0.9 & 1.6 \\
\hline $3 C$ & 2920 & 2936 & 2952 & -0.5 & -1.1 \\
\hline
\end{tabular}

From the collected data in these tables, it can be concluded that:

- The mass, volume, or cost of the battery-based architectures are affected by the minimum power level of the fuel cell.

- The battery-and-supercapacitor-based architecture and the supercapacitor-based architectures present the highest advantage of the FC minimum power increment, except architecture 3C. 
Architecture 3C shows a cost increment when the fuel cell minimum power increases due to the high number of power converters it uses.

- Since the mass and size reductions are very similar for the best architectures, the selection of the optimal architecture must be made based on the cost. So, regarding cost, the optimal architectures are $1 \mathrm{BC}$ and $1 \mathrm{C} 2$, which reduce their cost by $12 \%$.

- The last conclusion is related to the fuel cell hydrogen consumption. From the manufacturer's point of view, an increase in the delivered minimum power by the fuel cell implies a mass, volume, and cost reduction. However, at the same time, an increase in the delivered minimum power by the fuel cell means an increase in the energy delivered by the fuel cell throughout the working day. Therefore, the final user consumes more hydrogen every month.

Figure 8 shows, as an example, the evolution of the mass, volume, and cost, depending on the fuel cell maximum power, for a fuel cell minimum power equal to $400 \mathrm{~W}$ and for each architecture. This information has been used to obtain the data in Tables 3-5. As can be seen, each plot has three regions: only battery, battery and supercapacitor, and only supercapacitors. The $L_{\text {inf }}$ and $L_{\text {upp }}$ shown in Figure 8 (vertical gray lines) match with those shown in Figure $5 \mathrm{c}$ and separate the three design regions. For these conditions, the minimum mass, volume, and cost are obtained for a fuel cell maximum power around $5 \mathrm{~kW}$, inside the battery and supercapacitor region. Similar results are obtained when the fuel cell minimum power is $0 \mathrm{~W}$ and $200 \mathrm{~W}$, but with different limits and values, as shown in Tables 3-5.

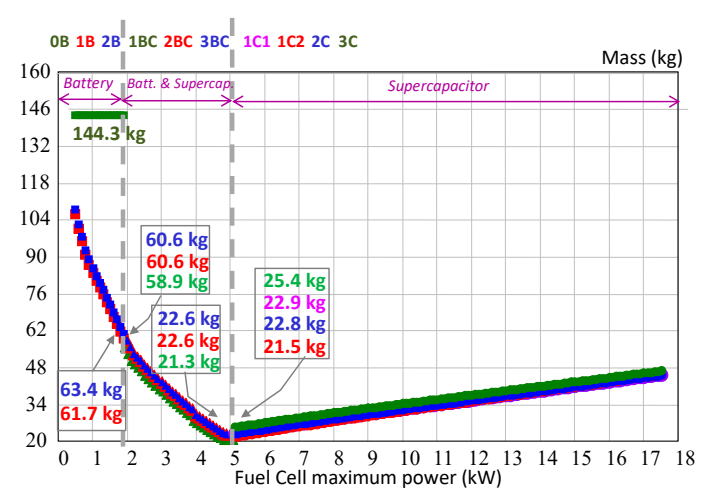

(a)

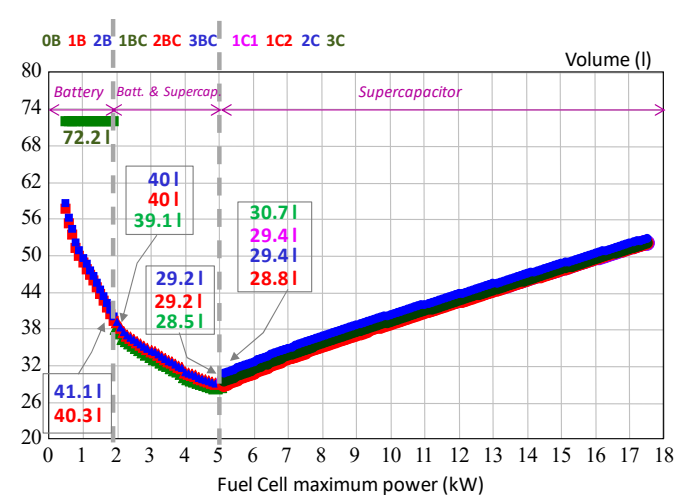

(b)

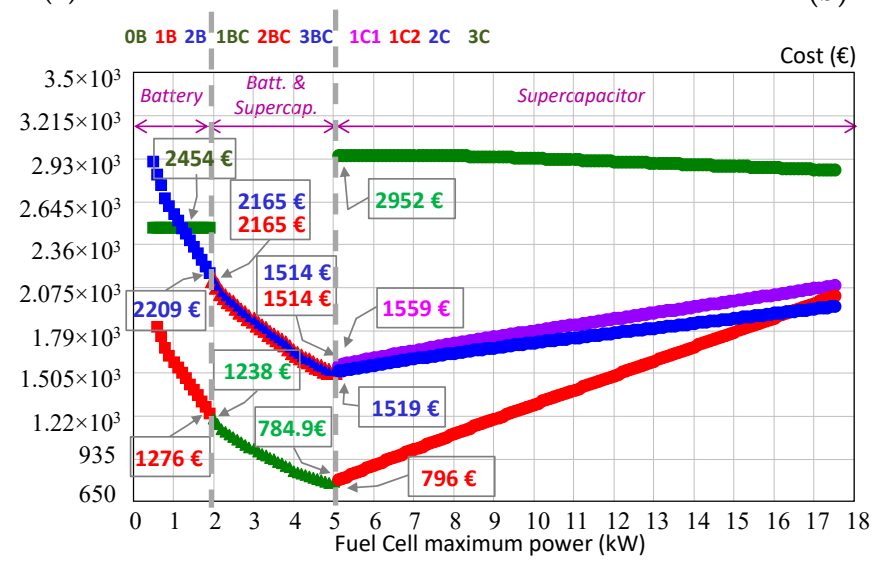

(c)

Figure 8. Analysis of every architecture depending on the fuel cell maximum power for a minimum fuel cell power of 400 W. (a) Mass. (b) Volume. (c) Cost.

\section{Influence of the Storage of the Energy Recovered from Regenerative Braking Periods}

This section describes the effect of considering the storage of the net amount of energy when the energy recovered from the regenerative braking is greater than the energy delivered by the secondary 
energy sources to complement the energy provided by the fuel cell. If such is the case, then the net amount of energy along the driving cycles in a working day $(8 \mathrm{~h})$ is negative, since the secondary energy sources charge in each cycle.

The power and energy that the secondary energy sources must provide are $P_{\text {diff }}(P)$ and $E_{\text {diff }}(P)$, which are determined as follows. The power $P_{\text {diff }}(P)$ is calculated as the difference between the peak power of the load profile and the maximum power delivered by the fuel cell, $P(W)$, as depicted in Figure 9 . On the other hand, the energy $E_{\text {diff }}(P)$ is the net amount of energy delivered by the secondary energy sources for all the driving cycles in a working day. This is the difference between the energy demanded by the load that the fuel cell is not able to provide (yellow areas in Figure 9) and the energy recovered and stored from the regenerative braking periods (blue areas) for all the driving cycles in the working day $(8 \mathrm{~h})$.

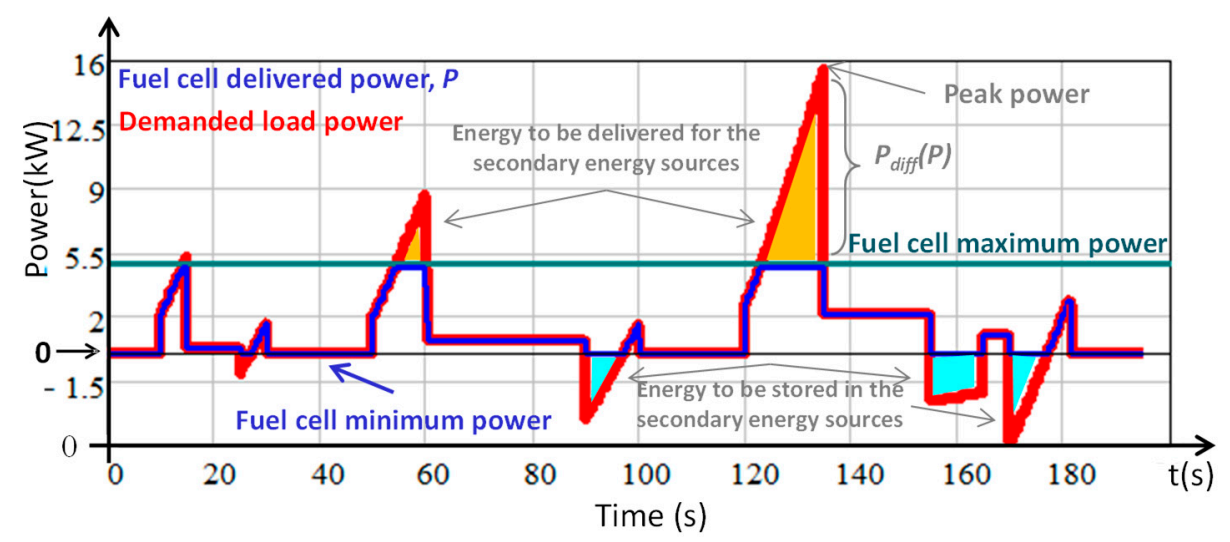

Figure 9. Demanded power by the load along one ECE-15 driving cycle.

The normalized battery mass obtained after applying the optimization procedure [23], including the possibility that the energy recovered from regenerative braking can be greater than the energy delivered by the secondary energy sources, is represented in Figure 10, as a function of the maximum power delivered by the fuel cell. As it can be seen, as the maximum fuel cell power increases, the net amount of energy that must be delivered by the secondary energy sources, $E_{\text {diff }}(P)$, decreases. However, it is expectable that for high values of fuel cell maximum power, the net amount of energy $E_{\text {diff }}(P)$ becomes negative since the energy recovered from the braking is bigger than the energy delivered to the load by the secondary energy sources. This effect is easily identifiable in Figure 10, and it corresponds to the turning point placed at $6.2 \mathrm{~kW}$.

In Figure 10, three different regions are highlighted based on the maximum power delivered by the fuel cell that minimizes the cost and mass in each region. For fuel cell maximum powers below $L_{\text {inf }}\left(0<P<L_{\text {inf }}\right)$, architectures that implement only batteries as secondary energy sources are the recommended ones. For $L_{\text {inf }}<P<L_{u p p}$, the use of batteries and supercapacitors as secondary energy sources is suggested. These two regions are only affected in the values of both the limits and the evolution of the normalized battery mass inside the region in which the batteries and supercapacitor are recommended. However, it is noticeable that now the architectures recommended for the third region $\left(P>L_{\text {upp }}\right)$ are no longer based on only supercapacitors, but they are based on implementing only batteries as secondary energy sources. 


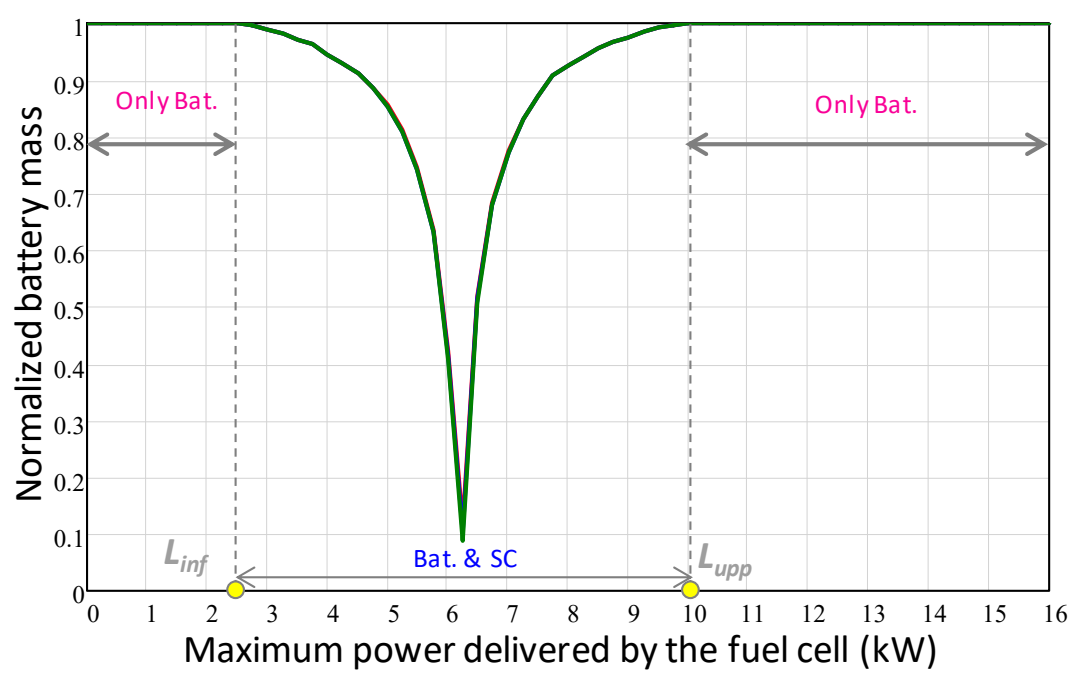

Figure 10. Normalized battery mass, considering the maximum energy delivered from the secondary energy sources during a driving cycle, as well as the storage of the energy from the regenerative braking periods, for the ECE-15 driving cycle.

Figures 11 and 12 show the cost and mass of architectures $1 \mathrm{~B}$ and $2 \mathrm{~B}$ in both the lower and the upper power ranges. It can be observed in Figure 11 that the mass and cost evolution of the propulsion systems $1 \mathrm{~B}$ and $2 \mathrm{~B}$ are not affected by considering that the energy from the regenerative braking periods is bigger than the energy demanded by the load that the fuel cell cannot satisfy throughout the $8 \mathrm{~h}$ working day.
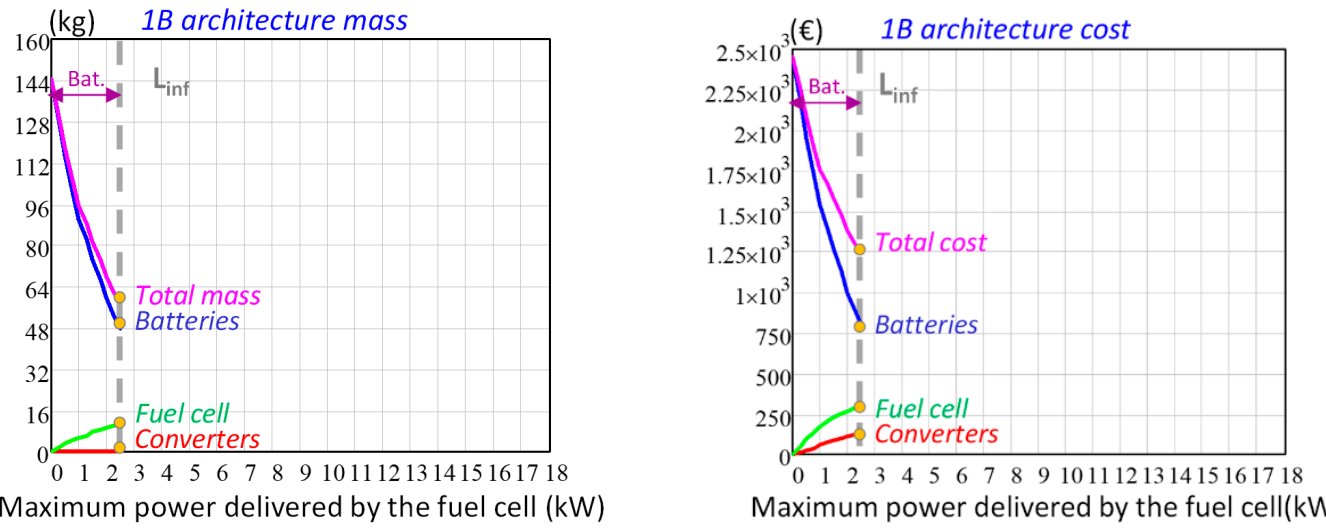

Maximum power delivered by the fuel cell $(\mathrm{kW})$

Maximum power delivered by the fuel cell(kW)
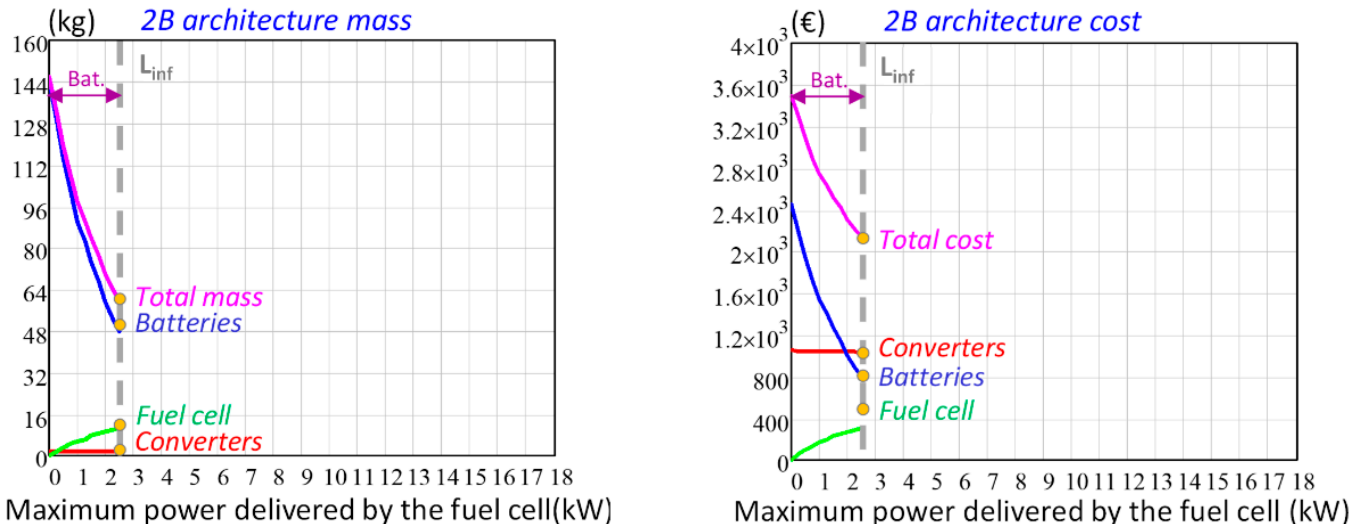

Maximum power delivered by the fuel cell $(\mathrm{kW})$

Maximum power delivered by the fuel cell $(\mathrm{kW})$

Figure 11. $1 \mathrm{~B}$ architecture cost and mass in the lowest design power range for the ECE-15 profile. 

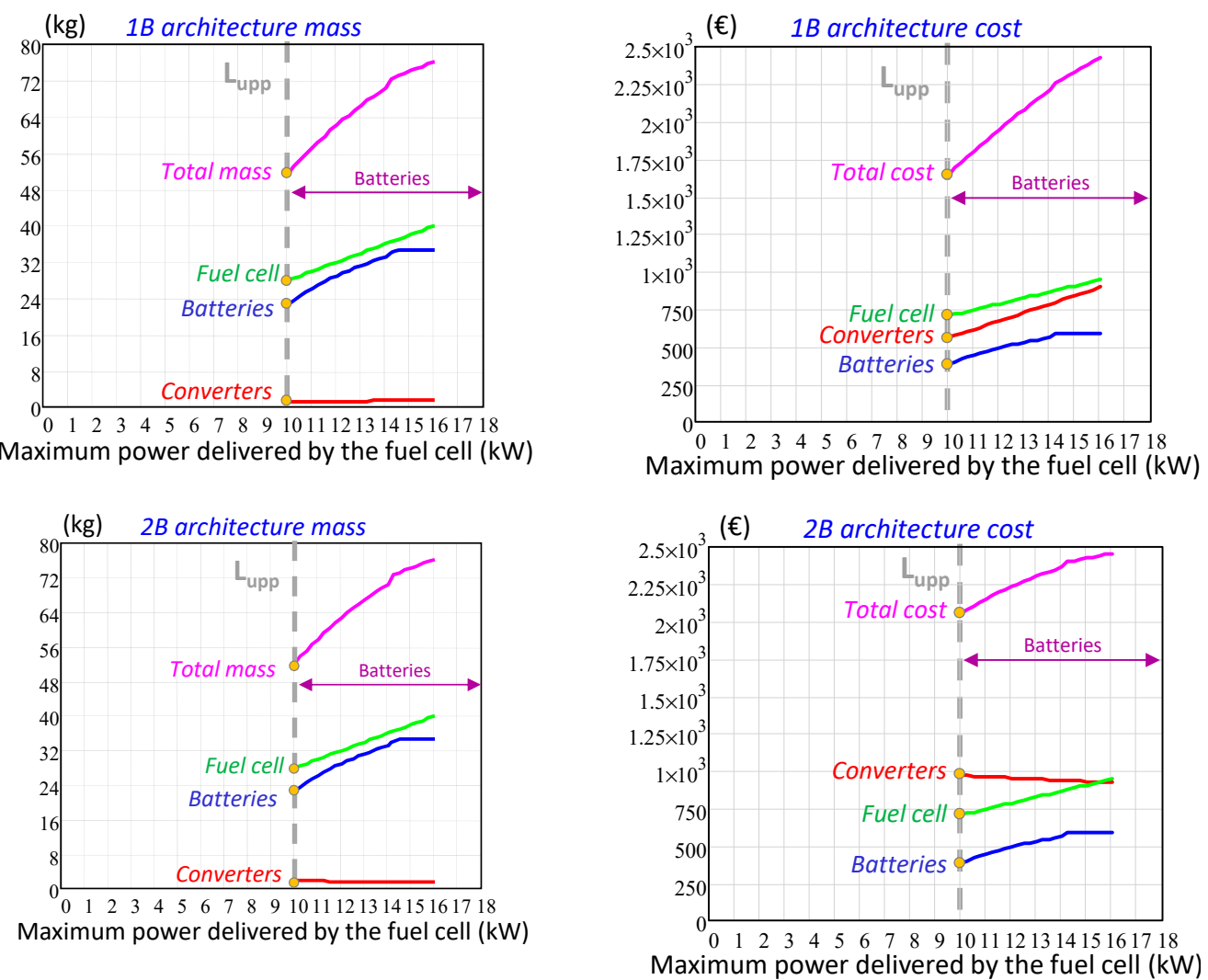

Figure 12. 1B architecture cost and mass in the highest design power range for the ECE-15 profile.

Figure 12 shows the mass and cost evolution of architectures $1 \mathrm{~B}$ and $2 \mathrm{~B}$ in the upper design power range, from $10 \mathrm{~kW}$ to $15.6 \mathrm{~kW}$. In both architectures, the minimum mass and cost are achieved at $L_{\text {upp }}$ $(10 \mathrm{~kW})$. It can be noticed that the higher the maximum power delivered by the fuel cell, the bigger the battery mass, since the batteries must be able to store a larger amount of remaining energy from the difference between the energy delivered to the load by the secondary energy sources and the energy recovered from the braking periods. Regarding the cost, it presents an increasing trend analogous to the battery mass increase as the maximum power of the fuel cell increases.

Therefore, Figures 11 and 12 show that architectures $1 \mathrm{~B}$ and $2 \mathrm{~B}$ have minimum mass when they are designed at $10 \mathrm{~kW}$, since the battery mass increment is lower than the mass increment experienced by the fuel cell. On the other hand, the minimum cost of powertrains $1 \mathrm{~B}$ and $2 \mathrm{~B}$ is achieved when they are designed at $2.5 \mathrm{~kW}$ due to the fact that the fuel cell and converter cost increments are bigger than the battery cost decrement.

Figure 13 depicts the mass and cost evolution as a function of the maximum power delivered by the fuel cell of powertrains $1 \mathrm{BC}, 2 \mathrm{BC}$, and $3 \mathrm{BC}$. In this case, all the architectures reach the minimum mass and cost at the turning point placed at $6.2 \mathrm{~kW}$. Also, it can be noticed that the total mass of powertrains $1 \mathrm{BC}, 2 \mathrm{BC}$, and $3 \mathrm{BC}$ is imposed by the fuel cell system mass, including the hydrogen tank. From the three architectures, $1 \mathrm{BC}$ presents the minimum mass. Regarding the cost, and due to the reduced number of power converters, propulsion system $1 B C$ is the cheapest. 


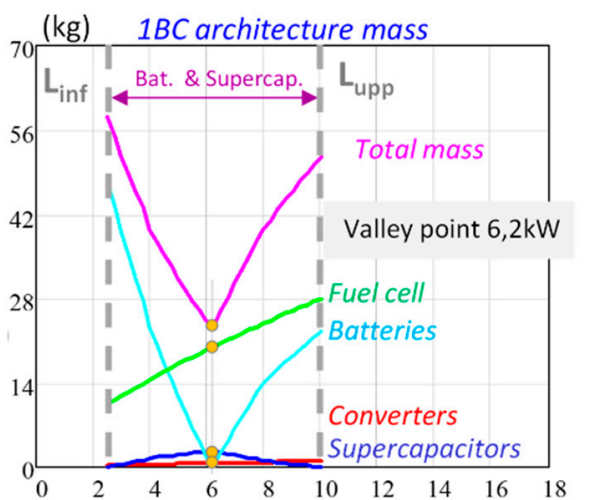

Maximum power delivered by the fuel cell $(\mathrm{kW})$

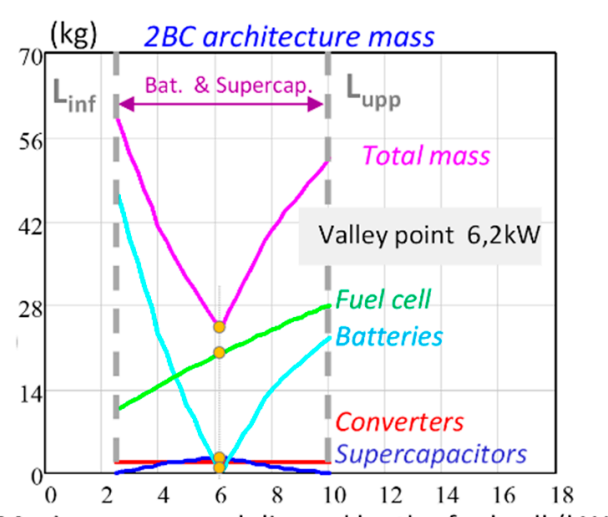

Maximum power delivered by the fuel cell $(\mathrm{kW})$

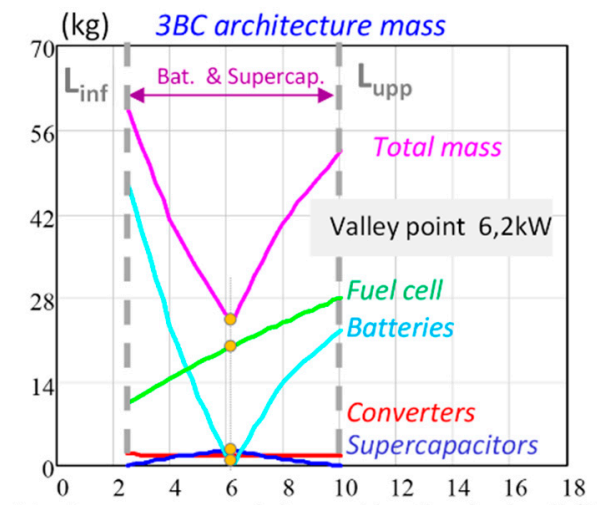

Maximum power delivered by the fuel cell $(\mathrm{kW})$

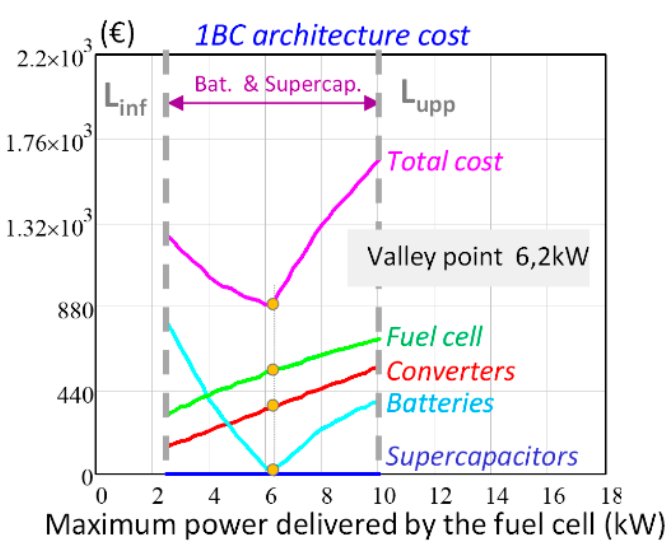

(a)

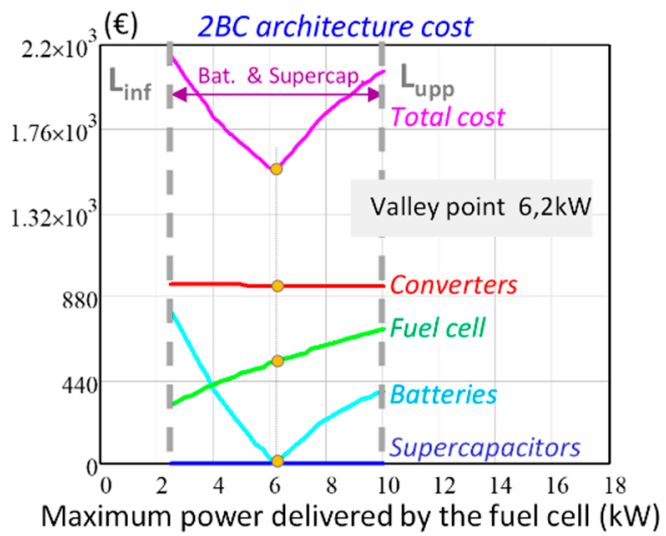

(b)

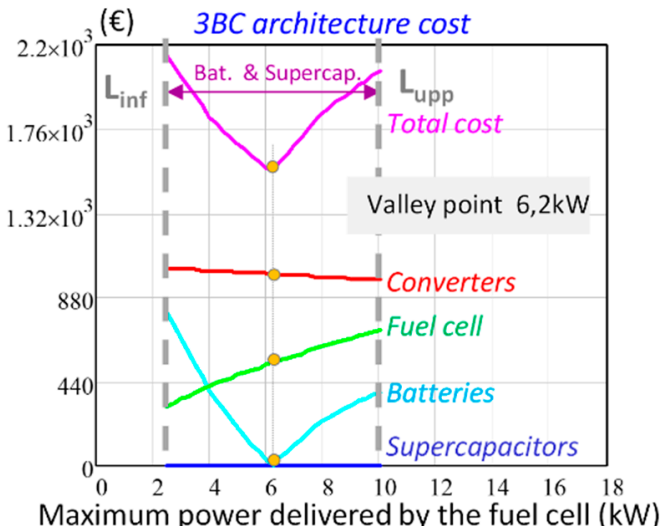

(c)

Figure 13. Total mass and total cost of PDS for the ECE-15 profile. (a) 1BC. (b) 2BC. (c) 3BC.

The main consequence of considering the storage of the net amount of energy when the energy recovered from the regenerative braking is bigger than the energy delivered by the secondary energy sources is the rearrangement of the three power design regions. For fuel cell power below $L_{\text {inf }}$, it is recommended to use of architectures that implement only batteries as secondary energy sources. For a fuel cell intermediate power range, $L_{i n f}<P<L_{u p p}$, the use of batteries and supercapacitors as secondary energy sources is suggested. Finally, for fuel cell power above $L_{u p p}$, the use of architectures based on implementing only batteries as secondary energy sources is again recommended. The optimal architectures are 1B (at $2.5 \mathrm{~kW}$ for minimum cost or $10 \mathrm{~kW}$ for minimum mass), and 1BC at $6.2 \mathrm{~kW}$. 


\section{Influence of the Battery Technology}

This section evaluates the influence of battery technologies on the optimal power ranges to correctly design each group of architectures. The analysis uses four different technologies: nickel-metal hydride, lead-acid, nickel-cadmium, and lithium-ion. The influence of these battery technologies is looked at independently of the influence of the other factors reviewed in previous sections. The data of power and energy density for each battery type are shown in Table 6.

Table 6. Power density, energy density, and price for each battery technology [32-35].

\begin{tabular}{ccccc}
\hline Parameter & Ni-MH & Lead-Acid & Ni-Cd & Li-ion \\
\hline Power density $(\mathrm{W} / \mathrm{kg})$ & 200 & 300 & 150 & 300 \\
Energy density $(\mathrm{Wh} / \mathrm{kg})$ & 60 & 30 & 40 & 100 \\
Price $(€ / \mathrm{kWh})$ & 400 & 100 & 140 & 170 \\
\hline
\end{tabular}

Table 7 summarizes the optimal data related to the mass, volume, and cost of the optimal architectures within each group of architecture when the four different battery technologies are applied. In all cases, each architecture has been evaluated within its optimal power range, with a maximum variation in the state-of-charge applied to the battery of 75\%, and using ECE-15 as the driving profile.

Table 7. Mass, volume, and cost of the architectures selected from each group, with the ECE-15 driving profile, and variation in the state-of-charge of the battery of $75 \%$, for lithium-ion, $\mathrm{Pb}$-acid, nickel-metal hydride, and nickel-cadmium.

\begin{tabular}{|c|c|c|c|c|c|c|c|c|c|c|c|c|}
\hline \multirow{2}{*}{$\begin{array}{l}\text { Bat. } \\
\text { Tech } \\
\text { Prop. } \\
\text { Syst. }\end{array}$} & \multicolumn{3}{|c|}{ Li-Ion } & \multicolumn{3}{|c|}{ Ni-MH } & \multicolumn{3}{|c|}{$\mathrm{Ni}-\mathrm{Cd}$} & \multicolumn{3}{|c|}{$\mathrm{Pb}$-Acid } \\
\hline & $\begin{array}{c}\text { Mass } \\
\text { (kg) }\end{array}$ & $\begin{array}{l}\text { Vol. } \\
\text { (L) }\end{array}$ & $\begin{array}{c}\text { Cost } \\
(€)\end{array}$ & $\begin{array}{c}\text { Mass } \\
\text { (kg) }\end{array}$ & $\begin{array}{l}\text { Vol. } \\
\text { (L) }\end{array}$ & $\begin{array}{c}\text { Cost } \\
(€)\end{array}$ & $\begin{array}{c}\text { Mass } \\
\text { (kg) }\end{array}$ & $\begin{array}{l}\text { Vol. } \\
\text { (L) }\end{array}$ & $\begin{array}{c}\text { Cost } \\
(€)\end{array}$ & $\begin{array}{c}\text { Mass } \\
\text { (kg) }\end{array}$ & $\begin{array}{l}\text { Vol. } \\
\text { (L) }\end{array}$ & $\begin{array}{c}\text { Cost } \\
(€)\end{array}$ \\
\hline 1B & 58.18 & 39.12 & 1256 & 79.3 & 50.8 & 2125 & 102.2 & 62.7 & 1041 & 55.6 & 43.1 & 869.9 \\
\hline $1 B C$ & 23.08 & 29.78 & 882.5 & 23.1 & 29.79 & 883 & 23.1 & 29.8 & 882.3 & 23.1 & 29.8 & 882.2 \\
\hline $1 \mathrm{C} 2$ & 23.25 & 29.98 & 887 & 23.25 & 29.98 & 887 & 23.25 & 29.98 & 887 & 23.25 & 29.8 & 887 \\
\hline
\end{tabular}

The fuel cell power limit affected by the different battery technologies is the lower one, $L_{\text {inf }}$ (see Figure 14a), which is the reason that only the cost, mass, and volume of the PDSs using batteries as the only secondary energy source are affected, as shown in Table 7. Architectures 1BC, 2BC, and 1C2 are not affected since their optimal mass, volume, and cost are calculated with a fuel cell maximum power different from the lower limit $\left(L_{\text {inf }}\right)$.

Figure 14a shows, for the four different battery technologies, the normalized battery mass along with the lower power limit. Depending on the $L_{\text {inf }}$ power limit, the amount of energy that the secondary energy source must be able to supply is modified (Table 8), and also their total required mass, as Figure 14b shows. The $L_{\text {inf }}$ and $L_{\text {upp }}$ power limits (yellow dots in Figure 14) represent the values of maximum power delivered by the fuel cell in which the optimal design changes the combination of secondary energy sources: that is, it changes from one region to another, e.g., using battery and supercapacitors instead of only battery, or using only supercapacitors instead of battery and supercapacitor [23].

Table 8. Maximum power limit delivered by the fuel cell for the optimal design of the $1 \mathrm{~B}$ architecture, and energy delivered by the battery using lithium-ion, lead-acid, nickel-metal hydride, and nickel-cadmium technologies.

\begin{tabular}{|c|c|c|c|c|c|c|c|c|}
\hline \multirow{2}{*}{$\begin{array}{c}\text { Bat. } \\
\text { Tech } \\
\text { Prop. } \\
\text { Syst }\end{array}$} & \multicolumn{2}{|c|}{ Li-ion } & \multicolumn{2}{|c|}{ Ni-MH } & \multicolumn{2}{|c|}{$\mathrm{Ni}-\mathrm{Cd}$} & \multicolumn{2}{|c|}{ Lead-Acid } \\
\hline & $\begin{array}{c}P_{\max } \mathrm{FC} \\
(\mathrm{kW})\end{array}$ & $\begin{array}{c}\text { Battery } \\
\text { Energy (Wh) }\end{array}$ & $\begin{array}{c}P_{\max } \mathrm{FC} \\
(\mathrm{kW})\end{array}$ & $\begin{array}{c}\text { Battery } \\
\text { Energy (Wh) }\end{array}$ & $\begin{array}{c}P_{\max } \mathrm{FC} \\
(\mathbf{k W})\end{array}$ & $\begin{array}{c}\text { Battery } \\
\text { Energy (Wh) }\end{array}$ & $\begin{array}{c}P_{\max } \text { FC } \\
(\mathbf{k W})\end{array}$ & $\begin{array}{c}\text { Battery } \\
\text { Energy (Wh) }\end{array}$ \\
\hline $1 \mathrm{~B}$ & 2.5 & 1040 & 3 & 920.15 & 3.2 & 872.17 & 5 & 459.87 \\
\hline
\end{tabular}




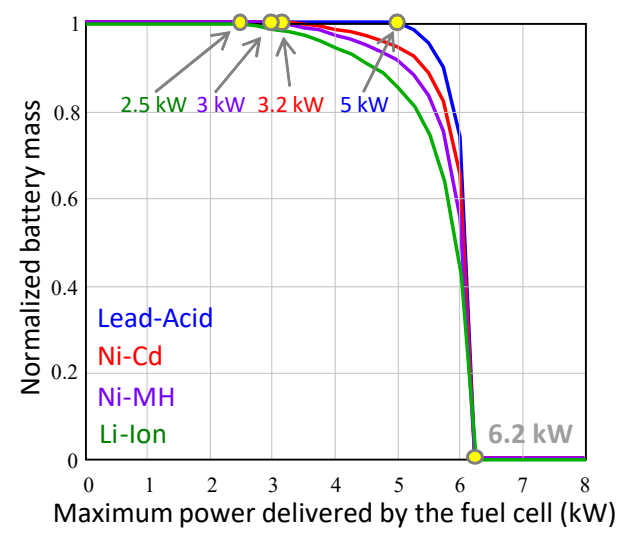

(a)

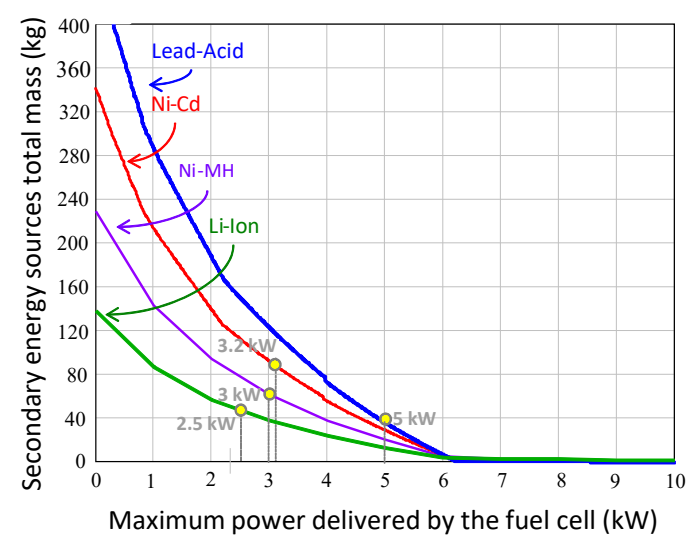

(b)

Figure 14. Mass of the battery and the secondary sources when lithium-ion, lead-acid, nickel-metal hydride, and nickel-cadmium batteries are used, considering the same vehicle with the ECE-15 driving profile and a variation in the state-of-charge of 75\%. (a) Normalized battery mass. (b) Total mass of secondary energy sources.

The batteries with a larger relation between energy density and power density, in addition to bringing forward lower $L_{i n f}$ (Figure 14a), require a lower secondary power source total mass for the same load requirements (Figure 14b). That is, with fewer kilograms of battery, more energy is supplied.

Table 7 shows that the total mass of powertrain 1B increases as the ratio of energy density to power density in the battery becomes lower, except for lead-acid ones. The reason for this exception is that, in the lead-acid battery technology, $L_{i n f}$ of the fuel cell for the designed architectures is very high at $5 \mathrm{~kW}$ (see Figure 14a), which means that the battery manages significantly less energy (Table 8), and, therefore, its mass decreases, as can be seen in Figure 15a.

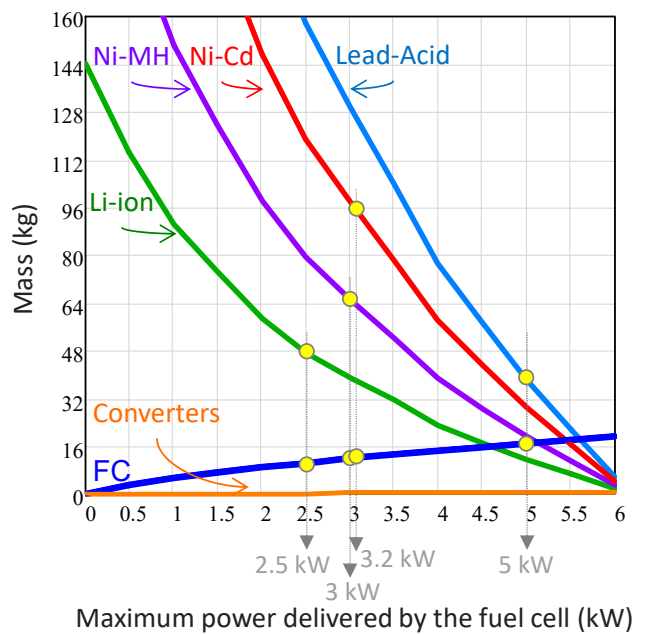

(a)

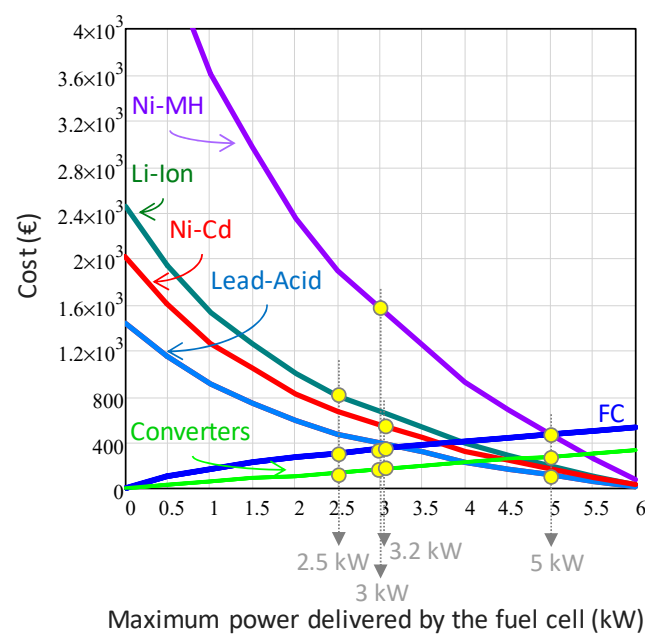

(b)

Figure 15. The fuel cell system and the converter of powertrain $1 \mathrm{~B}$ with different battery technologies, with a variation in the state-of-charge of $75 \%$, when the ECE-15 driving profile is applied. (a) Mass. (b) Cost.

Regarding the overall cost of the $1 \mathrm{~B}$ architecture, two aspects must be taken into account when different battery technologies are applied: the fuel cell maximum power along with the power density of the technology, and the price per kWh of each technology. It is observed that the higher cost is obtained by using Ni-MH battery technology due to its high mass and price, while the lower cost is obtained by using lead-acid battery technology (Figure 15b) due to its reduced mass. 
Finally, it can be concluded that battery technology has a high influence on the total mass, volume, and cost of PDSs that only implement batteries as secondary energy sources. The lower the ratio of the energy density to the power density of the battery, the higher the power limit $L_{\text {inf }}$. Consequently, the use of more powerful fuel cells implies the selection of batteries that manage less energy, and, therefore, its total mass is lower. The battery technologies that provide PDSs with higher total mass, in ascending order, are lead-acid, lithium-ion, nickel-metal hydride, and nickel-cadmium (see the yellow dots in Figure 15a). Similarly, in ascending order, the technologies that provide the most expensive power distribution systems are lead-acid, nickel-cadmium, lithium-ion, and nickel-metal hydride (see the yellow dots in Figure 15b). The amount of energy that manages the battery in each case is significantly different, as seen in Table 8 , since the optimal design is found for a different fuel cell maximum power.

\section{Influence of the Battery State-of-Charge Variation}

Finally, this section evaluates the influence of the allowed maximum battery state-of-charge variation on the optimal design of each group of PDSs.

$L_{\text {inf }}$ is the only fuel cell power limit affected by the variations of the state-of-charge of the batteries (Figure 16a), and the reason is that only the optimal cost, mass, and volume of the batteries are affected in powertrains using batteries as the only secondary energy source. The total mass of the secondary sources is shown in Figure 16b for when the variation in the state-of-charge of the battery is $50 \%$ and $75 \%$. It can be concluded that the larger the allowed variation in the state-of-charge, the lower the value of $L_{\text {inf }}$, and the lower the mass of the secondary energy sources.

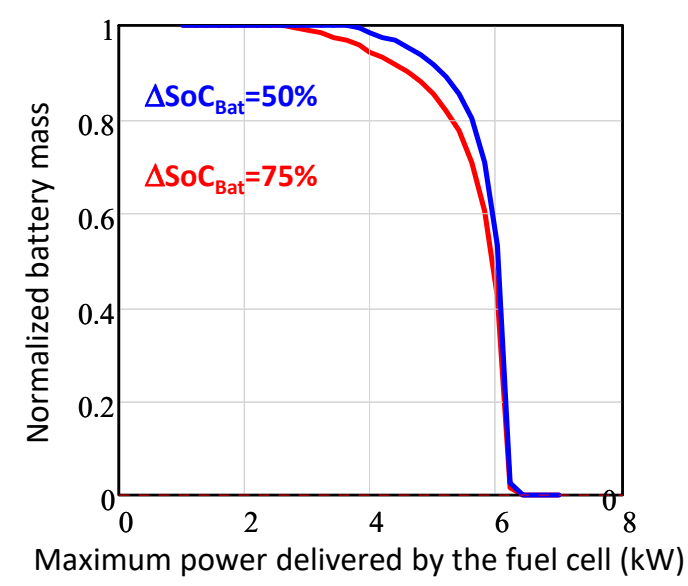

(a)

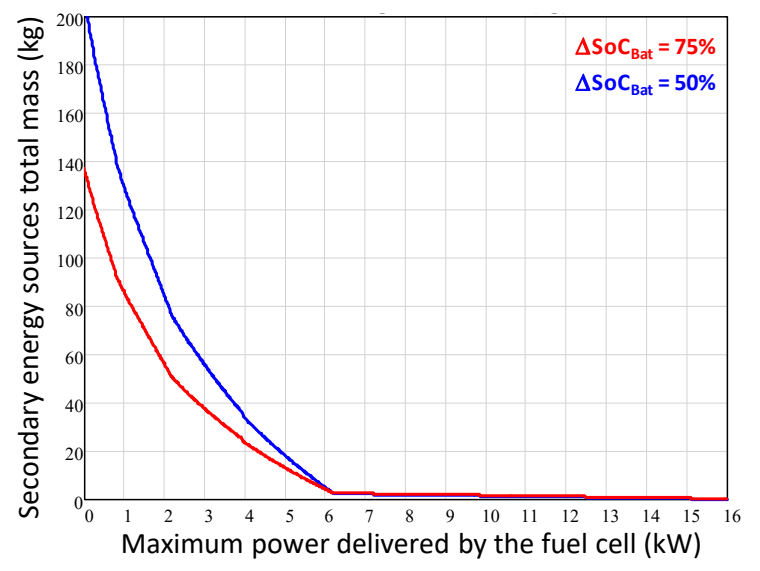

(b)

Figure 16. Identification of the optimal design power range for each group of architectures, depending on the variation in the state-of-charge of the battery. (a) Normalized battery mass. (b) Total mass of secondary energy sources.

Table 9 shows the mass, volume, and cost of the electric power distribution systems 1B, 1BC, and $1 \mathrm{C} 2$ for the ECE- 15 driving profile when the variation in the state-of-charge of the battery is $50 \%$ and $75 \%$. 
Table 9. Mass, volume, and overall cost of the electric power distribution systems selected from each group of architectures, with variations in the battery charge state of 50\% and $75 \%$, for the ECE-15 driving profile.

\begin{tabular}{ccccccc}
\hline ECE-15 & \multicolumn{3}{c}{$\Delta$ SoC $_{\text {Bat }}=\mathbf{0 . 5}$} & \multicolumn{3}{c}{$\Delta S o C_{\text {Bat }}=\mathbf{0 . 7 5}$} \\
\hline Architecture & Mass (kg) & Vol. (L) & Cost (€) & Mass (kg) & Vol. (L) & Cost (€) \\
\hline 1B & 56.6 & 40.86 & 1323 & 58.18 & 39.12 & 1256 \\
1BC & 23.1 & 29.79 & 882.85 & 23.08 & 29.78 & 882.48 \\
1C2 & 23.25 & 29.98 & 887.02 & 23.25 & 29.98 & 887 \\
\hline
\end{tabular}

A lower variation in the state-of-charge implies higher maximum power delivered by the fuel cell, that is, an increase in the lower limit $L_{\text {inf }}$ of maximum power delivered by the fuel cell (Figure 16a). As a result of the increase in the maximum power delivered by the fuel cell, there is an increase in the mass of the fuel cell itself, an increase in the mass of the converters, and a reduction in the total mass required from secondary energy sources. In particular, if powertrain 1B is analyzed, a decrease in the allowed variation in the state-of-charge in the battery involves reducing the mass of the battery itself, along with an increase in the mass of the fuel cell system and the converters. As the mass reduction of the battery is greater than the mass increment of the fuel cell system along with the converters, architecture $1 \mathrm{~B}$ shows a lower value of its total mass when the variation in the state-of-charge is lower (Figure 17a). The influence of varying the state-of-charge of the battery on the overall volume of the architectures is analogous to the influence owing to the mass.

Regarding the cost, it can be seen in Table 9 that the lower the maximum variation in the state-of-charge of the battery, the higher the overall cost of the PDS. In Figure 17b, it is verified that a smaller allowed variation in the state-of-charge of the battery implies a higher value of $L_{\text {inf }}$, which is the lower limit of the maximum power of the fuel cell for the proposed electric power distribution systems. Therefore, a lower variation in the state-of-charge of the battery causes a lower cost of the battery and higher cost of the converter and fuel cell system. The increase in the cost of the converter and of the fuel cell system is more significant than the decrease in the battery cost, because the overall cost of the electric power distribution system increases when a smaller state-of-charge of the battery is allowed.

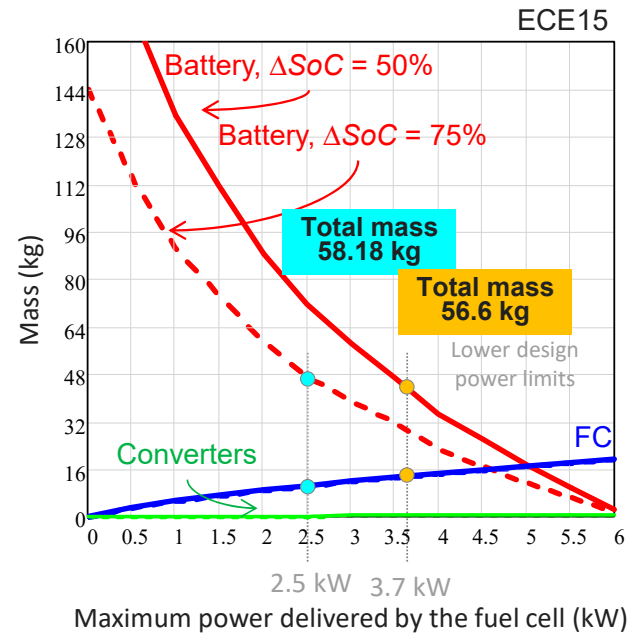

(a)

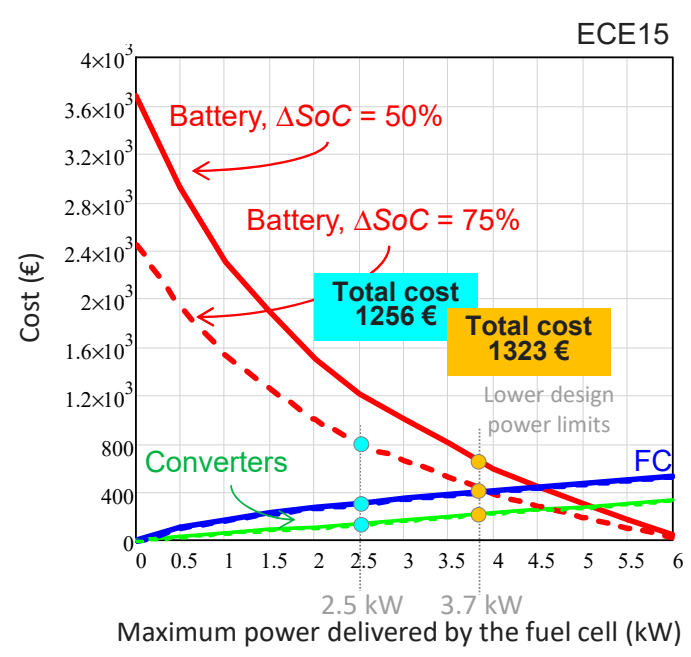

(b)

Figure 17. Evolution of the mass and the cost of the battery of the fuel cell system and the converters of electric power distribution system $1 \mathrm{~B}$, with variations in the state-of-charge of the battery of $50 \%$ and $75 \%$ for the ECE-15 driving profile. (a) Battery mass. (b). Battery cost. 
The conclusion is that the variation in the state-of-charge of the batteries affects fundamentally the architectures that implement only batteries as a secondary energy source. A greater variation in the state-of-charge implies higher secondary energy source total mass, a higher PDS mass, as well as a lower design power limit of the fuel cell, $L_{\text {inf }}$. These results are strongly dependent on the evolution of the price and the battery technology.

\section{Conclusions}

This paper analyzes, using the optimal sizing procedure described in [23] as a baseline, the influence of four different design factors on the size and cost of nine different propulsion systems based on the fuel cell, batteries and supercapacitors, and a pure battery vehicle. Also, it reviews an additional design factor presented in [28]. All the analyses have been carried out considering a light vehicle of $800 \mathrm{~kg}$ when the driving cycle is applied during a working day of $8 \mathrm{~h}$. The result of the analysis is the knowledge of how the main design factors affect the mass, volume, and cost of the optimal power distribution architectures, and how they can be considered in the design.

Regarding the influence of the driving profile, there are different power range limits suggested for the architectures based on batteries, batteries and supercapacitors, or supercapacitors to optimize mass, cost, and volume. However, the optimal power distribution architectures are the same and independent of the applied driving profile. These optimal PDSs are 1B, 1BC, and 1C2. Also, in the case where the energy and power delivery by the battery and the supercapacitors in the $1 \mathrm{BC}$ architecture cannot be controlled independently, the $1 \mathrm{BC}$ architecture can be replaced by the $2 \mathrm{BC}$ architecture. A more detailed explanation can be found in [28].

Attending to the influence of the minimum power delivered by the fuel cell, as the minimum fuel cell power increases, the power range limits are shifted toward lower power values since the amount of energy that the fuel cell delivers is bigger. The size and cost of the architectures based on batteries and supercapacitors and based on only supercapacitors decrease as the minimum delivered power by the fuel cell increases. The preferred power distribution architectures, 1B, 1BC, and 1C2, are the same and independent of the minimum energy delivered by the fuel cell.

The storage of the energy from the regenerative braking periods throughout a working day $(8 \mathrm{~h})$ also affects the PDS design. It can be remarked that as the fuel cell maximum power increases, the net amount of energy delivered by the secondary energy sources decreases. Therefore, there is a maximum fuel cell power beyond which the net amount of energy becomes negative. That is, the energy recovered from the braking periods is larger than the energy delivered by the secondary energy sources to fulfill the load demand that the fuel cell cannot. This consideration modifies the recommended architectures for the highest fuel cell maximum power range $\left(P>L_{u p p}\right)$, dismissing those architectures that are based on only supercapacitors as a secondary energy source, and suggesting the use of architectures with secondary energy sources implemented using only batteries. On the other hand, for the lower fuel cell power level, the recommended architectures are still the same: for $P<L_{\text {inf }}$, the use of only batteries as a secondary source is suggested, while, for $L_{\text {inf }}<P<L_{u p p}$, the recommended secondary source combines the use of supercapacitors and batteries. As a conclusion, for this case, the final suggested recommendation is the use of architecture $1 \mathrm{~B}$ at $2.5 \mathrm{~kW}$ with the objective of minimizing the cost, or at $10 \mathrm{~kW}$ with the objective of minimizing the mass, and architecture $1 \mathrm{BC}$ at $6.2 \mathrm{~kW}$.

The battery technology has a high influence on the total mass, volume, and cost of PDSs that only implement batteries as a secondary energy source. The lower the ratio of the energy density to the power density of the battery, the greater the power limit $L_{\text {inf }}$. Consequently, the use of more powerful fuel cells implies the selection of batteries that manage less energy, and, therefore, its total mass is lower. The battery technologies that provide PDSs with higher total mass, in ascending order, are lead-acid, lithium-ion, nickel-metal hydride, and nickel-cadmium. Similarly, in ascending order, the technologies that provide the most expensive power distribution systems are lead-acid, nickel-cadmium, lithium-ion, and nickel-metal hydride. 
Finally, the variation in the state-of-charge affects those architectures that implement only batteries as secondary energy sources. A greater variation in the state-of-charge implies, for the $1 \mathrm{~B}$ architecture, higher secondary energy source total mass, a higher PDS mass, as well as a lower design power limit of the fuel cell, $L_{\text {inf }}$. In any case, these results are strongly dependent on the evolution of the price and the battery technology.

Author Contributions: C.R. did theoretical analysis, derivation, data processing, and wrote the first original draft paper. A.B. was responsible for funding acquisition, supervision and administration, his contribution was related to the theoretical analysis, data analysis, and the paper reviewing and editing. A.L. contributed to theoretical analysis and supervision. I.Q. helped with the derivation and to write the first original draft paper. A.M.-L helped to write the last version of the draft paper. P.Z. contributed useful comments on the main paper contributions.

Funding: This research was funded by the Spanish Ministry of Economy and Competitiveness and ERDF, grant number DPI2014-53685-C2-1-R.

Acknowledgments: This work has been partially supported by the Spanish Ministry of Economy and Competitiveness and FEDER (ERDF), through the research project "Storage and Energy Management for Hybrid Electric Vehicles based on Fuel Cell, Battery and Supercapacitors"—ELECTRICAR-AG—(DPI2014-53685-C2-1-R).

Conflicts of Interest: The authors declare no conflict of interest.

\section{References}

1. International Energy Agency. Global EV Outlook 2018; OECDiLibrary: Paris, France, 2018. [CrossRef]

2. Hyundai's First Mass-Produced Tucson Fuel Cell CUVs Arrive in Southern California. Available online: https://www.hyundai.com/content/hyundai/worldwide/en/news/news-room/news/hyundai\%27sfirst-mass-produced-tucson-fuel-cell-cuvs-arrive-in-southern-california-0000002989.html (accessed on 22 October 2018).

3. Jensen, H.C.B.; Schaltz, E.; Koustrup, P.S.; Andreasen, S.J.; Kaer, S.K. Evaluation of Fuel-Cell Range Extender Impact on Hybrid Electrical Vehicle Performance. IEEE Trans. Veh. Technol. 2013, 62, 50-60. [CrossRef]

4. Raga, C.; Barrado, A.; Lazaro, A.; Fernandez, C.; Valdivia, V.; Quesada, I.; Gauchia, L. Black-Box Model, Identification Technique and Frequency Analysis for PEM Fuel Cell With Overshooted Transient Response. IEEE Trans. Power Electron. 2014, 29, 5334-5346. [CrossRef]

5. Adzakpa, K.P.; Agbossou, K.; Dube, Y.; Dostie, M.; Fournier, M.; Poulin, A. PEM Fuel Cells Modeling and Analysis Through Current and Voltage Transient Behaviors. IEEE Trans. Energy Convers. 2008, 23, 581-591. [CrossRef]

6. Raga, C.; Barrado, A.; Lazaro, A.; Quesada, I.; Lopez del Moral, D.; Valdivia, V. Black-box model and identification methodology for PEM fuel cell with overdamped transient response. In Proceedings of the 2012 IEEE Energy Conversion Congress and Exposition (ECCE), Raleigh, NC, USA, 15-20 September 2012; pp. 1176-1181.

7. Ravey, A.; Member, S.; Watrin, N.; Blunier, B.; Bouquain, D.; Miraoui, A.; Member, S. Energy-Source-Sizing Methodology for Hybrid Fuel Cell Vehicles Based on Statistical Description of Driving Cycles. IEEE Trans. Veh. Technol. 2015, 60, 4164-4174. [CrossRef]

8. Marx, N.; Hissel, D.; Gustin, F.; Boulon, L.; Agbossou, K. On the sizing and energy management of an hybrid multistack fuel cell-Battery system for automotive applications. Int. J. Hydrog. Energy 2017, 42, 1518-1526. [CrossRef]

9. Feroldi, D.; Carignano, M. Sizing for fuel cell/supercapacitor hybrid vehicles based on stochastic driving cycles. Appl. Energy 2016, 183, 645-658. [CrossRef]

10. $\mathrm{Hu}, \mathrm{X}$; Johannesson, L.; Murgovski, N.; Egardt, B. Longevity-conscious dimensioning and power management of the hybrid energy storage system in a fuel cell hybrid electric bus. Appl. Energy 2015, 137, 913-924. [CrossRef]

11. Hu, X.; Murgovski, N.; Johannesson, L.M.; Egardt, B. Optimal dimensioning and power management of a fuel cell/battery hybrid bus via convex programming. IEEE/ASME Trans. Mechatron. 2015, 20, 457-468. [CrossRef]

12. Raga, C.; Barrado, A.; Quesada, I.; Lazaro, A.; Sanz, M. Control strategy improvement for a parallel power distribution architecture based on fuel cells and supercapacitors. In Proceedings of the 2009 Compatability and Power Electronics, Badajoz, Spain, 20-22 May 2009; pp. 419-425. 
13. Hu, Z.; Li, J.; Xu, L.; Song, Z.; Fang, C.; Ouyang, M.; Dou, G.; Kou, G. Multi-objective energy management optimization and parameter sizing for proton exchange membrane hybrid fuel cell vehicles. Energy Convers. Manag. 2016, 129, 108-121. [CrossRef]

14. Hegazy, O.; Van Mierlo, J. Particle swarm optimization for optimal powertrain component sizing and design of fuel cell hybrid electric vehicle. In Proceedings of the 12th International Conference on Optimization of Electrical and Electronic Equipment, Basov, Romania, 20-22 May 2010. [CrossRef]

15. Kamali-Nejad, M.; Azib, T.; Remy, G.; Bethoux, O.; Marchand, C. Optimization of a power electronic structure for hybrid Fuel Cell/Ultracapacitors vehicle. In Proceedings of the 2010 IEEE Vehicle Power and Propulsion Conference, Lille, France, 1-3 September 2010; pp. 1-6.

16. Cai, Q.; Brett, D.J.L.; Browning, D.; Brandon, N.P. A sizing-design methodology for hybrid fuel cell power systems and its application to an unmanned underwater vehicle. J. Power Sources 2010, 195, 6559-6569. [CrossRef]

17. Rotenberg, D.; Vahidi, A.; Kolmanovsky, I. Ultracapacitor assisted powertrains: Modeling, control, sizing, and the impact on fuel economy. IEEE Trans. Control Syst. Technol. 2011, 19, 576-589. [CrossRef]

18. Hu, X.; Murgovski, N.; Johannesson, L.M.; Egardt, B. Comparison of Three Electrochemical Energy Buffers Applied to a Hybrid Bus Powertrain With Simultaneous Optimal Sizing and Energy Management. IEEE Trans. Intell. Transp. Syst. 2014, 15, 1193-1205. [CrossRef]

19. Bubna, P.; Advani, S.G.; Prasad, A.K. Integration of batteries with ultracapacitors for a fuel cell hybrid transit bus. J. Power Sources 2012, 199, 360-366. [CrossRef]

20. Lopes, J.; Pomilio, J.A.; Ferreira, P.A.V. Optimal sizing of batteries and ultracapacitors for fuel cell electric vehicles. In Proceedings of the IECON 2011-37th Annual Conference of the IEEE Industrial Electronics Society, Melbourne, VIC, Australia, 7-10 November 2011; pp. 4603-4608.

21. Yu, Z.; Zinger, D.; Bose, A. An innovative optimal power allocation strategy for fuel cell, battery and supercapacitor hybrid electric vehicle. J. Power Sources 2011, 196, 2351-2359. [CrossRef]

22. Doucette, R.T.; McCulloch, M.D. A comparison of high-speed flywheels, batteries, and ultracapacitors on the bases of cost and fuel economy as the energy storage system in a fuel cell based hybrid electric vehicle. J. Power Sources 2011, 196, 1163-1170. [CrossRef]

23. Raga, C.; Barrado, A.; Miniguano, H.; Lazaro, A.; Quesada, I.; Martin-Lozano, A.; Raga, C.; Barrado, A.; Miniguano, H.; Lazaro, A.; et al. Analysis and Sizing of Power Distribution Architectures Applied to Fuel Cell Based Vehicles. Energies 2018, 11, 2597. [CrossRef]

24. Calderon, C.; Barrado, A.; Rodriguez, A.; Lazaro, A.; Sanz, M.; Olias, E. Dual active bridge with triple phase shift, soft switching and minimum RMS current for the whole operating range. In Proceedings of the IECON 2017-43rd Annual Conference of the IEEE Industrial Electronics Society, Beijing, China, 29 October-1 November 2017; pp. 4671-4676.

25. Calderon, C.; Barrado, A.; Rodriguez, A.; Alou, P.; Lazaro, A.; Fernandez, C.; Zumel, P. General Analysis of Switching Modes in a Dual Active Bridge with Triple Phase Shift Modulation. Energies 2018, 11, 2419. [CrossRef]

26. Grabarek, M.; Parchomiuk, M.; Strzelecki, R. Conjugated control of triple active bridge converter with common HFT. In Proceedings of the 2017 11th IEEE International Conference on Compatibility, Power Electronics and Power Engineering (CPE-POWERENG), Cadiz, Spain, 4-6 April 2017; pp. 304-307.

27. Chattopadhyay, R.; Bhattacharya, S. Decoupled power flow using phase shift control and ZVS cases for a three limb high frequency transformer based three-port DAB integrating PV and energy storage. In Proceedings of the 2016 IEEE Industry Applications Society Annual Meeting, Portland, OR, USA, 2-6 October 2016. [CrossRef]

28. Raga, C.; Barrado, A.; Lazaro, A.; Quesada, I.; Sanz, M.; Zumel, P. Driving profile and fuel cell minimum power analysis impact over the size and cost of fuel cell based propulsion systems. In Proceedings of the 2015 9th International Conference on Compatibility and Power Electronics (CPE), Costa da Caparica, Portugal, 24-26 June 2015; pp. 390-395.

29. Cubito, C.; Millo, F.; Boccardo, G.; Di Pierro, G.; Ciuffo, B.; Fontaras, G.; Serra, S.; Otura Garcia, M.; Trentadue, G.; Cubito, C.; et al. Impact of Different Driving Cycles and Operating Conditions on $\mathrm{CO}_{2}$ Emissions and Energy Management Strategies of a Euro-6 Hybrid Electric Vehicle. Energies 2017, 10, 1590. [CrossRef] 
30. Schwarzer, V.; Ghorbani, R. Drive Cycle Generation for Design Optimization of Electric Vehicles. IEEE Trans. Veh. Technol. 2013, 62, 89-97. [CrossRef]

31. Henao, N.; Kelouwani, S.; Agbossou, K.; Dube, Y. PEMFC low temperature startup for electric vehicle. In Proceedings of the IECON 2012-38th Annual Conference on IEEE Industrial Electronics Society, Montreal, QC, Canada, 25-28 October 2012; pp. 2977-2982.

32. European Automobile Manufacturers Association. A Review of Battery Technologies for Automotive Applications. Available online: https://www.acea.be/publications/article/a-review-of-batterytechnologies-for-automotive-applications (accessed on 22 October 2018).

33. Hadjipaschalis, I.; Poullikkas, A.; Efthimiou, V. Overview of current and future energy storage technologies for electric power applications. Renew. Sustain. Energy Rev. 2009, 13, 1513-1522. [CrossRef]

34. Khaligh, A.; Li, Z. Battery, Ultracapacitor, Fuel Cell, and Hybrid Energy Storage Systems for Electric, Hybrid Electric, Fuel Cell, and Plug-In Hybrid Electric Vehicles: State of the Art. IEEE Trans. Veh. Technol. 2010, 59, 2806-2814. [CrossRef]

35. Gao, Y.; Ehsani, M. Investigation of battery technologies for the army's hybrid vehicle application. In Proceedings of the IEEE 56th Vehicular Technology Conference, Vancouver, BC, Canada, 24-28 September 2002; pp. 1505-1509.

(C) 2018 by the authors. Licensee MDPI, Basel, Switzerland. This article is an open access article distributed under the terms and conditions of the Creative Commons Attribution (CC BY) license (http:/ / creativecommons.org/licenses/by/4.0/). 